Review Article

\title{
Review on Selection and Experiment Method of Commonly Studied Simulated Radionuclides in Researches of Nuclear Waste Solidification
}

\author{
Jingwei Li $\mathbb{D},{ }^{1}$ Dong Xu, ${ }^{2}$ Wenlong Wang $\mathbb{D}^{1},{ }^{1}$ Xujiang Wang, ${ }^{1}$ Yanpeng Mao, ${ }^{1}$ Chao Zhang, \\ Wen Jiang, ${ }^{1}$ and Changliang $\mathrm{Wu}^{1}$ \\ ${ }^{1}$ Shandong Engineering Laboratory for Solid Waste Green Materials, \\ National Engineering Laboratory for Reducing Emissions from Coal Combustion, \\ Engineering Research Center of Environmental Thermal Technology of Ministry of Education, \\ Shandong Key Laboratory of Energy Carbon Reduction and Resource Utilization, School of Energy and Power Engineering, \\ Shandong University, Jinan 250014, China \\ ${ }^{2}$ School of Civil Engineering, Shandong Jianzhu University, Jinan 250101, China
}

Correspondence should be addressed to Jingwei Li; ljw@sdu.edu.cn and Wenlong Wang; wwenlong@sdu.edu.cn

Received 21 February 2020; Revised 3 June 2020; Accepted 12 June 2020; Published 28 August 2020

Academic Editor: Arkady Serikov

Copyright (c) 2020 Jingwei Li et al. This is an open access article distributed under the Creative Commons Attribution License, which permits unrestricted use, distribution, and reproduction in any medium, provided the original work is properly cited.

Although many types of simulated radionuclides have been widely used as a substitute for actual nuclear waste in the studies of nuclear waste solidification, the understanding of the applicability and validity of simulated radionuclides is still insufficient. In particular, the selection and use of simulated radionuclides, which can play a decisive role in the accuracy of the experimental results, still lack unified or integrated references. This paper provides a critical review on the selection, experimental methods, and applicability of the most commonly studied simulated radionuclides, followed by a careful discussion and recommendation of simulated radionuclides suitable for different solidified bodies. The main factors (e.g., temperature, $\mathrm{pH}$, and atmosphere) affecting the choice of simulated radionuclides were analyzed in detail. This work helps to integrate the selection and use of simulated radionuclides, and it will be beneficial for improving the effectiveness of nuclide solidification research.

\section{Introduction}

Nuclear energy is a high-efficiency energy source with high energy density, low cost, and no air pollution emission [1]. However, the nuclear facilities of nuclear power, medicine, scientific research, industry, and agriculture can generate large amounts of nuclear waste during operation and decommissioning $[2,3]$. Nuclear waste contains more than 30 radioactive elements, mainly including actinides (such as $\mathrm{Pu}$ and $\mathrm{U}$ ), fission elements (such as $\mathrm{Cs}, \mathrm{Sr}, \mathrm{I}, \mathrm{Xe}$, and $\mathrm{Ru}$ ), and other radioactive elements, which can emit radioactive alpha rays ( $\alpha$-rays), beta rays ( $\beta$-rays), and gamma rays $(\gamma$-rays) during the decay of the nucleus, and X-rays by atomic shell electron transitions [4-6]. Nuclear waste can cause irreversible radioactive contamination to air, land, and water due to the high radioactivity and radiotoxicity [7].
When the human body is exposed to high doses of radiation, radioactive substances can cause irreversible damage to the human body, causing mutations in human cells and cancer $[7,8]$. Based on two parameters, the radionuclide half-life and radioactivity, the International Atomic Energy Agency (IAEA) classified radioactive waste into five categories: very short-lived waste (VSLW), very low-level waste (VLLW), low-level waste (LLW), intermediate-level waste (ILW), and high-level waste (HLW) [7]. The main sources and types of radionuclides in nuclear waste are shown in Table 1. It can be seen that radionuclides and their isotopes are widely distributed in facilities, water, waste residues, and other wastes.

It is necessary to properly treat and dispose of nuclear waste for long-term safe and cost-effective management. Among the various nuclear waste management procedures, the immobilization treatment and geological disposal 
TABLE 1: Main sources and types of radionuclides $[4,6]$.

\begin{tabular}{lcccc}
\hline Sources & Radionuclide & Form & Type & Waste form \\
\hline $\begin{array}{l}\text { Uranium mining and } \\
\text { manufacturing }\end{array}$ & ${ }^{226} \mathrm{Ra},{ }^{238} \mathrm{U},{ }^{234} \mathrm{U},{ }^{235} \mathrm{U}$ & Solid & $\alpha, \gamma$ & Waste ore, resin, plastic, tailings, residue, waste \\
equipment
\end{tabular}

methods are most widely used [7, 9]. Concrete and cement composites are widely used for LLW and ILW immobilization due to their good physical, chemical, and mechanical properties as well as low prices [10-12]. The common method for HLW immobilization is to form borosilicate glass or ceramic composites by vitrification or the melt process $[8,13]$. Many studies [14-18] have been conducted to investigate the immobilization characteristics, mechanism, and effectivity of various solidifying materials on nuclear waste. The main purposes of these studies are summarized as developing new solidifying materials, increasing the loading of radioactive waste, reducing the leaching of radionuclides, enhancing the mechanical strength of solidified bodies, and reducing the disposal difficulty and cost. Additionally, computer simulation methods [13, 19-23], such as quantum mechanical and empirical models of atomic bonding, density functional theory plus Hubbard $U$ correction $(D F T+U)$, energy minimization, molecular dynamics (MD), and Monte Carlo (MD) methods, have also been widely applied to study the radiation effects in various solidified bodies.

In most cases, actual nuclear wastes could not be used in these studies due to their radioactive, corrosive, and other harmful properties to the human body. In addition, it is unpractical to study the radiation damage to the solidified bodies for hundreds of years or even thousands of years through actual experiments [2, 24]. Researchers [24-27] found that some nonradioactive isotopes of the radionuclides or some other nonradioactive elements had similar physical and chemical properties to the corresponding radionuclides. These nonradioactive isotopes or elements have been widely used as the simulated radionuclides to test or evaluate the solidification effect of solidifying materials on nuclear waste. Some simulated radionuclides commonly used in existing studies are shown in Table 2.

Although various kinds of simulated radionuclides $\left(\mathrm{Cs}^{+}\right.$, $\mathrm{Sr}^{2+}, \mathrm{Co}^{2+}, \mathrm{Pu}^{4+}, \mathrm{Ce}^{4+}, \mathrm{I}^{-}$, and $\left.\mathrm{IO}_{3}^{-}\right)$and solidified bodies (cement, glass, ceramic, polymer, pollucite, geopolymer, etc.) have been used in existing studies, the understanding of the applicability and validity of simulated radionuclides is still insufficient. Some important issues about simulated radionuclides still exist including the following: why these kinds of simulated radionuclides are chosen, and are they suitable? How should they be used, and are the experimental results valid? Choosing proper simulated radionuclides and experimental methods is very important to obtain effective research results. For example, (i) $\mathrm{Cs}^{+}$can be used as the simulated radionuclides of ${ }^{137} \mathrm{Cs}$ in the studies of cement solidified ${ }^{137} \mathrm{Cs}[10,28,29] . \mathrm{pH}$ and temperature are one of the most important parameters and concerns for the success of the solidification/stabilization treatment of cement $[40,41]$. In this case, $\mathrm{CsNO}_{3}$ or $\mathrm{CsCl}$ is often used as the resource of $\mathrm{Cs}^{+}[28,29,42,43]$ because they are soluble in water with little heat release, and the aqueous solution is nearly neutral, which will have little influence on the hydration of cement and the experimental results. However, $\mathrm{Cs}_{2} \mathrm{CO}_{3}$ and $\mathrm{CsOH}$ are not suggested to be used in cement waste forms because their aqueous solutions are highly alkaline (e.g., for $50 \mathrm{~g} / \mathrm{L} \mathrm{Cs}_{2} \mathrm{CO}_{3}, \mathrm{pH}=10 \sim 13$; $\mathrm{CsOH}$ has an even higher $\mathrm{pH}$ than $\mathrm{Cs}_{2} \mathrm{CO}_{3}$ ), and a lot of heat is released when $\mathrm{CsOH}$ dissolves in water. The use of $\mathrm{Cs}_{2} \mathrm{CO}_{3}$ or $\mathrm{CsOH}$ might adversely affect the research results and lead to lowconfidence research conclusions. (ii) Ceramic is considered to be an ideal host for HLW [44, 45], and some researchers $[14,20,23]$ used $\mathrm{Cs}_{2} \mathrm{CO}_{3}$ or $\mathrm{CsNO}_{3}$ to prepare Cs-containing ceramic waste forms by calcining the raw materials to over $1000^{\circ} \mathrm{C}$. Differently, the preparation of $\mathrm{Pu}-$ (or Ce-) containing ceramic waste forms needs special treatment to reduce $\mathrm{Pu}(\mathrm{IV})$ (or $\mathrm{Ce}(\mathrm{IV})$ ) to $\mathrm{Pu}(\mathrm{III})$ (or $\mathrm{Ce}(\mathrm{III})$ ) $[25,46]$. However, $\mathrm{Pu}(\mathrm{IV})$ (or $\mathrm{Ce}(\mathrm{IV})$ ) can cause a structural change from the ordered pyrochlore to a disordered defect fluorite, which may adversely affect the study of actual solidification forms [46]. Different simulated radionuclides may be treated differently in the same kind of solidified body. Therefore, the selection and use of simulated radionuclides can play a decisive role in the accuracy of the research results. 
TABLE 2: Simulated radionuclides commonly used in former studies.

\begin{tabular}{lcc}
\hline Radionuclides & Simulated nuclides and source compounds & Immobilization scheme \\
\hline${ }^{137} \mathrm{Cs}$ & $\mathrm{Cs}^{+}-\mathrm{CsNO}_{3}, \mathrm{CsCl}, \mathrm{CsOH}, \mathrm{Cs}_{2} \mathrm{CO}_{3}[10,15,28,29]$ & \\
${ }^{90} \mathrm{Sr}$ & $\mathrm{Sr}^{2+}-\mathrm{SrCl}_{2} \cdot 6 \mathrm{H}_{2} \mathrm{O}, \mathrm{Sr}(\mathrm{OH})_{2}, \mathrm{SrCO}_{3}, \mathrm{SrSO}_{4}, \mathrm{SrF}_{2}$, & Immobilization in cement, pollucite, glass, ceramic, polymer, \\
${ }^{60} \mathrm{Sr}\left(\mathrm{NO}_{3}\right)_{2}[30-34]$ & geopolymer, inorganic mineral, etc. \\
${ }^{239} \mathrm{Pu}$ & $\mathrm{Co}^{2+}-\mathrm{Co}\left(\mathrm{NO}_{3}\right)_{2} \cdot 6 \mathrm{H}_{2} \mathrm{O}, \mathrm{CoCl}_{2} \cdot 6 \mathrm{H}_{2} \mathrm{O}[29,35,36]$ & \\
${ }^{129} \mathrm{I}$ & $\mathrm{Pu}^{4+}, \mathrm{Ce}^{4+}-\mathrm{PuO}_{2}, \mathrm{CeO}_{2}[24,25,37]$ & \\
\hline
\end{tabular}

However, despite common usage worldwide, there are no unified or integrated references for the selection and experimental method of the commonly studied simulated radionuclides.

This paper is oriented to review the selection, kinds, and experimental methods of simulated radionuclides commonly studied in the research of nuclear waste solidification. The advantages and disadvantages of the simulated radionuclides in different solidification conditions are discussed. The primary objective of the work is to (i) advance the understanding of various solidification approaches of nuclear waste and the role of simulated radionuclides and (ii) provide comprehensive references for the selection and use of simulated radionuclides in different solidification materials for nuclear waste solidification studies.

\section{Simulants of ${ }^{137} \mathrm{Cs}$ and Experimental Methods}

Fission product ${ }^{137} \mathrm{Cs}$ is one of the most important artificial radionuclides generated from nuclear reactors, nuclear weapon tests, radioactive wastes, or waste liquid [20]. It is a gamma emitter with radiotoxicity, high volatility, mobility, and a relatively long half-life (close to 30 years) [47], which can be present in LLW, ILW, and HLW [48]. When ${ }^{137} \mathrm{Cs}$ permeates into the food chain and is transferred to the human body, it can cause respiratory disease, acute and chronic injury, and even soft tissue tumors. Therefore, nuclear waste containing ${ }^{137} \mathrm{Cs}$ must be pretreated and stabilized prior to disposal for the sake of preventing it from leaching into the environment [27].

${ }^{137} \mathrm{Cs}$ has been classified as an easy-to-measure nuclide, which can be used as the signal nuclide for nuclear power plant accidents [49]. It is reported that solid-phase or liquidphase ${ }^{137} \mathrm{Cs}$ exists in an oxide form such as $\mathrm{Cs}_{2} \mathrm{MoO}_{4}$, $\mathrm{Cs}_{2} \mathrm{UO}_{4}$, or $\mathrm{Cs}_{2} \mathrm{ZrO}_{3}$ in spent fuels [50-52], and the gaseousphase Cs is considered to exist in $\mathrm{Cs}_{2} \mathrm{CO}_{3}(\mathrm{~g}), \mathrm{CsOH}(\mathrm{g})$, and CsI (g) [53-55]. Thus, many studies were conducted to investigate the immobilization characteristics of solid-phase and liquid-phase ${ }^{137} \mathrm{Cs}$, and $\mathrm{Cs}^{+}$was the most used simulant of ${ }^{137} \mathrm{Cs}$ due to the similarity in physical and chemical properties.

2.1. Simulated ${ }^{137} \mathrm{Cs}$ in the Immobilization Method by Using Cementitious Material. Cementitious materials have been widely used for radioactive waste solidification as long-term storage and disposal materials due to the good physical, chemical, and mechanical properties [11, 28, 56, 57]. Since the cement-based systems have presented the gradual dissolution and leaching of radionuclides, many studies have been conducted to improve this stabilization technique [58-61]. $\mathrm{CsNO}_{3}$ or $\mathrm{CsCl}$ was often used as the simulant of ${ }^{137} \mathrm{Cs}$ in those studies of cementitious material immobilization methods. The experimental methods of cementitious material solidification experiments for ${ }^{137} \mathrm{Cs}$ are relatively simple and usually include the dissolution of simulated ${ }^{137} \mathrm{Cs}$, solidification, leaching tests, chemical tests, and mechanical performance tests.

Fan et al. investigated the effects of ferrihydrite nanoparticle incorporation in cementitious materials on radioactive waste immobilization [10]. In the experimental process, the cement-based solidified body for simulated ${ }^{137} \mathrm{Cs},{ }^{238} \mathrm{U}$, and ${ }^{90} \mathrm{Sr}$ was prepared first. The mass proportion of each simulated radionuclide in the solidified body was set as approximately 4\%. First, $\mathrm{CsNO}_{3} \quad(0.72 \mathrm{~g})$, $\mathrm{UO}_{2}\left(\mathrm{NO}_{3}\right)_{2} \cdot 6 \mathrm{H}_{2} \mathrm{O}(1.85 \mathrm{~g})$, and $\mathrm{Sr}\left(\mathrm{NO}_{3}\right)_{2}(0.78 \mathrm{~g})$ were dissolved in $20 \mathrm{~mL}$ of ultrapure water to prepare the radioactive waste solution. Then, $20 \mathrm{~mL}$ of simulated solution and $5 \mathrm{~mL}$ of suspension were added into $50 \mathrm{~g}$ of Type I ordinary Portland cement and mixed to reach a welldispersed coherent state. The mixture was cast into a cylinder mold, demolded after $24 \mathrm{~h}$, and then cured in at $20 \pm 1^{\circ} \mathrm{C}$ and a relative humidity $(\mathrm{RH})$ of $45 \pm 5 \%$ for 28 days before the leaching test. In the end, the leaching test was conducted following the standard method of ANSI/ANS16.1-2003R2008 (American National Standard Measurement of the Leachability of Solidified Low-Level Radioactive Wastes by a Short-Term Test Procedure). In another study [28], $\mathrm{CsNO}_{3}$ was added into the used matrix (ordinary Portland cement blended with blast furnace slag), and the mass proportion of Cs was 3\% in the total matrix.

In the study of the immobilization of the simulated radionuclide ${ }^{133} \mathrm{Cs}^{+}$by fly ash-based geopolymer [15], $\mathrm{CsNO}_{3}$ (analytical reagent grade) was used as the simulated radionuclide. Before being mixed with ordinary Portland cement and fly ash in proportion, $\mathrm{CsNO}_{3}$ was first dissolved in deionized water to form a homogeneous solution. The mass proportion of $\mathrm{Cs}$ in the resulting geopolymer/cement mixture was $2 \%$. The mixtures were made into $20 \mathrm{~mm} \times 20 \mathrm{~mm} \times 20 \mathrm{~mm}$ cubes and then cured in humid air with a relative humidity $(\mathrm{RH})$ of $90 \pm 1 \%$ and a temperature of $60 \pm 0.5^{\circ} \mathrm{C}$. In addition to microstructural and mineralogical analysis, leaching tests (long-term leaching, simulated environment leaching, and acid corrosion tests) and mechanical performance tests (compressive strength, freezethaw performance, and high-temperature performance tests) were also conducted to study the performance of the solidified body. Jang et al. used similar experimental 
methods to study the physical barrier effect of the geopolymer waste form on the diffusivity of Cs and Sr [62], and the difference was that the nuclide simulants were $\mathrm{CsCl}$ and $\mathrm{SrCl}_{2} \cdot 6 \mathrm{H}_{2} \mathrm{O}$.

$\mathrm{Cs}^{+}$-compounds, which have the properties of water solubility, room temperature stability, and low toxicity, which can be selected as the simulants of ${ }^{137} \mathrm{Cs}$ in the experiments. According to former studies, the mass proportion of $\mathrm{Cs}^{+}$in the cementitious mixture was no more than $5 \%$, and ICP-MS or ICP-OES was usually used to quantitatively analyze $\mathrm{Cs}^{+}$in the leaching test.

The advantage of $\mathrm{CsNO}_{3}$ and $\mathrm{CsCl}$ is that their aqueous solutions are close to neutral, and thus, they have less of an effect on cement solidification. One challenge associated with $\mathrm{CsNO}_{3}$ and $\mathrm{CsCl}$ is matching the amount dissolved in water with the water-cement ratio during the solidification experiments.

2.2. Simulated ${ }^{137} \mathrm{Cs}$ in the Immobilization Method by Using Pollucite. Pollucite belongs to the group of analcime zeolites, and the specific structure of pollucite is beneficial to hold Cs ions tightly and avoid leaching in aqueous media $[63,64]$. The thermal stability of pollucite has been confirmed to be excellent relative to several cesium aluminosilicate minerals [65]. Therefore, pollucite $\left(\mathrm{CsAlSi}_{2} \mathrm{O}_{6}\right)$ may be feasible as one of the final phases to dispose of ${ }^{137} \mathrm{Cs}$-containing waste for extended periods of time [66-68]. Pollucite can be synthesized by the hydrothermal route (Figure S1) or recrystallized by heat treatment [69-71].

Chen et al. investigated the method of the hydrothermal conversion of Cs-polluted soil into pollucite for ${ }^{137} \mathrm{Cs}$ immobilization [18]. In the experiment, alumina was mixed with ground soil to form certain molar ratios of $\mathrm{Al} / \mathrm{Si}$, and then, 5 mass $\% \mathrm{CsOH}$ solutions were added into the mixture at $\mathrm{Cs} / \mathrm{Al} / \mathrm{Si}$ ratios of $1 / 1 / 5,1 / 1.5 / 5,1 / 2 / 5$, and $1 / 2.5 / 5$, respectively, in order to synthesize pollucite. The specimens were pressed in a stainless rectangular-shaped mold and then cured for various setting times (0-24h) in a Teflonlined stainless steel autoclave at setting temperatures $\left(100-240^{\circ} \mathrm{C}\right)$ for pollucite preparation. The pollucite $\left(\mathrm{CsAlSi}{ }_{2} \mathrm{O}_{6} \cdot x \mathrm{H}_{2} \mathrm{O}\right)$ samples showed low flexural strength $(5 \mathrm{MPa})$. With the addition of $\mathrm{Ca}(\mathrm{OH})_{2}$, a strong solidified body was synthesized, which showed the highest flexural strength of $30 \mathrm{MPa}$. EXAFS measurements were performed to investigate the coordination environments of the synthesized pollucite and further confirm the coordination state of $\mathrm{Cs}$ in the synthesized pollucite structure. According to the EXAFS test, the polluted Cs was immobilized into the structure of the synthesized pollucite. The leaching test of Cs in pollucite samples was conducted according to ASTM C 1285-02 (American Society for Testing Material, 2008) [72], rather than ANSI/ANS-16.1-2003R2008. The ASTM C 128502 method is suitable for glass waste forms or multiphase glass ceramics [72]. Pollucite can be converted into ceramic by calcination and is also suitable for this leaching test method. This hydrothermal technology showed potential to directly immobilize the ${ }^{137} \mathrm{Cs}$-polluted soil.
Montagna et al. also studied the storage of ${ }^{137} \mathrm{Cs}$ by borosilicate and aluminosilicate pollucite nanocrystals [48]. $\mathrm{CsOH}$, silica sources (precipitation silica Zeosil 175MP Rhône-Poulenc or fumed silica Aerosil 200), $\mathrm{H}_{3} \mathrm{BO}_{3}, \mathrm{NaOH}$, and aluminum $(\mathrm{AlOOH})$ hydroxides were mixed at certain molar ratios $(0.22 \leq(\mathrm{B}+\mathrm{Al}) / \mathrm{Si} \leq 0.43,0 \leq \mathrm{B} /(\mathrm{B}+\mathrm{Al}) \leq 1$, and $0.10 \leq \mathrm{Cs} /(\mathrm{Na}+\mathrm{Cs}) \leq 1)$. The mixtures were sealed in a stainless steel autoclave and then heated for 2-30 days at $115-195^{\circ} \mathrm{C}$ to prepare pollucite crystalline materials.

The process of Cs-pollucite preparation is relatively simple. Similar methods were also applied in other researches $[67,70,73,74]$, and the pollucite was verified to incorporate Cs into the crystalline structure, which presented an excellent immobilization effect on Cs. The advantage of $\mathrm{CsOH}$ is that it does not introduce any other ions except for $\mathrm{O}$ and $\mathrm{H}$ into the synthesis reaction of pollucite, and the reaction products are only pollucite and $\mathrm{H}_{2} \mathrm{O}$, which is conducive to the purity of the prepared pollucite. However, $\mathrm{CsOH}$ is highly corrosive and should be placed in a sealed container that is stored in a cool, dry place.

\subsection{Simulated ${ }^{137} \mathrm{Cs}$ in the Immobilization Method by Using} Glass Waste Forms. Glass waste forms have the potential to provide durable, wide-ranging, and good radiation resistance immobilization of HLW $[26,75,76]$. Sohn et al. studied the stability of $\mathrm{Cs}$ and $\mathrm{Sr}$ in Na-aluminoborosilicate glasses [77]. In this study, three glass compositions were prepared based on the following systems: $\mathrm{Na}_{2} \mathrm{O}-\mathrm{Al}_{2} \mathrm{O}_{3}-\mathrm{B}_{2} \mathrm{O}_{3}-\mathrm{SiO}_{2}-\mathrm{Cs}_{2} \mathrm{O}$ (system NABS-Cs), $\mathrm{Na}_{2} \mathrm{O}-\mathrm{Al}_{2} \mathrm{O}_{3}-\mathrm{B}_{2} \mathrm{O}_{3}-\mathrm{SiO}_{2}-\mathrm{SrO}$ (system NABS-Sr), and $\mathrm{Na}_{2} \mathrm{O}-\mathrm{Al}_{2} \mathrm{O}_{3}-\mathrm{B}_{2} \mathrm{O}_{3}-\mathrm{SiO}_{2}-\mathrm{SrO}-\mathrm{Cs}_{2} \mathrm{O}$ (system NABS-SrCs). The preparation process of glass samples is described as follows: (i) simulated nuclides $\left(\mathrm{Cs}_{2} \mathrm{CO}_{3}\right.$ and $\left.\mathrm{SrCO}_{3}\right)$ and reagent-grade $\mathrm{Na}_{2} \mathrm{CO}_{3}$ were preheated and decarbonated at $850^{\circ} \mathrm{C}$ for over 30 minutes; (ii) reagent-grade $\mathrm{B}_{2} \mathrm{O}_{3}, \mathrm{Al}_{2} \mathrm{O}_{3}$, and $\mathrm{SiO}_{2}$ were dried at $1200^{\circ} \mathrm{C}$ for over 20 minutes; (iii) these reagents were weighed and mixed according to the set ratios and then melted in a platinum crucible at $1200^{\circ} \mathrm{C}$ for $1 \mathrm{~h}$; (iv) the melt was quenched, and the obtained glass was crushed and ground; and (v) the melting and grinding process was conducted twice. This experimental method enabled the preparation of glass samples with a fairly homogeneous chemical composition, and most simulated nuclides were immobilized in crystalline materials during the devitrification of the glasses. The prepared glasses were analyzed by a JEOL 733 electron microprobe to check the chemical change by melting. The analyzed mass proportions of $\mathrm{Cs}_{2} \mathrm{O}$ and $\mathrm{SrO}$ were $4.54 \%-13.71 \%$ and $4.97 \%-10.44 \%$, respectively, in the aluminoborosilicate glasses. The results showed that the $\mathrm{Cs}_{2} \mathrm{O}$ content in the samples decreased markedly (2\%-3\%) because $\mathrm{Cs}_{2} \mathrm{CO}_{3}$ was partially decomposed and volatilized during melting. Compared with $\mathrm{Cs}_{2} \mathrm{O}$, the $\mathrm{SrO}$ content was almost unchanged.

To investigate the influence of the hydrothermal reaction between glass and water on $\mathrm{Cs}$ and $\mathrm{Sr}$ immobilization, this study conducted hydrothermal treatment of the prepared glass samples. The powdered glass samples were sealed in a gold capsule with deionized water and then heated in an autoclave at $200^{\circ} \mathrm{C}$ with a vapor pressure of $1.54 \mathrm{MPa}$ for 60 days. The heating temperature was 
determined according to the maximum temperature $\left(150-200^{\circ} \mathrm{C}\right)$ in the deep geological repositories in the first few hundred years after disposal [78]. The produced crystalline phases were identified as Analcime-type zeolite by the XRD method. Cs and Sr were found to be fixed in the analcime-type zeolite (Figure S2). The experimental methods in this study have great reference value for the preparation method of ${ }^{137} \mathrm{Cs}$ - (or ${ }^{90} \mathrm{Sr}$-) containing glasses as well as the hydrothermal treatment of the glasses for the hydrothermal reaction study. Similar methods were also used in related studies [79-82].

In mixed alkali glasses (e.g., $\mathrm{Na}-\mathrm{K}$ or $\mathrm{Na}-\mathrm{Cs}$ silicate glasses), physical properties such as the electrical conductivity, molar volume, glass transition temperature, and thermal expansion coefficient can be nonlinear due to the mixed alkali effect (MAE) $[83,84]$. The MAE has attracted much attention because it is very important for developing unique glass materials with a controllable electrical conductivity or thermal expansion coefficient, respectively $[19,85]$. Kaneko et al. [19] prepared borosilicate ( $\mathrm{Si}: \mathrm{B}=1: 1$ ) and $\mathrm{Si}$-rich borosilicate $(\mathrm{Si}: \mathrm{B}=2: 1)$ glasses containing alkali cations $\mathrm{Cs}^{+}$and $\mathrm{Na}+$ to study the MAE on nuclides solidification. In the preparation process of the glass samples, chemically pure $\mathrm{Cs}_{2} \mathrm{CO}_{3}$ together with $\mathrm{SiO}_{2}, \mathrm{~B}(\mathrm{OH})_{3}$, and $\mathrm{Na}_{2} \mathrm{CO}_{3}$ were used to prepare the glass samples by the melting method (temperatures of $1350^{\circ} \mathrm{C}, 1100^{\circ} \mathrm{C}$, and $1350^{\circ} \mathrm{C}$ for silicate, borate, and borosilicate glasses, resp.). The $\mathrm{Cs}^{+} /\left(\mathrm{Cs}^{+}+\mathrm{Na}^{+}\right)$ratios were set at $0.0,0.2,0.5,0.8$, and 1.0. XRD was used to identify the crystal structures of the synthesized samples. A strong magnetic field MAS NMR was used to examine the structure of mixed alkali borosilicate glasses for the sake of correlating the MAE with the alkali environment. An AVANCE III spectrometer using a commercial probe ( $4 \mathrm{~mm}$ ) was used to acquire the solid-state ${ }^{133} \mathrm{Cs}$ and ${ }^{23} \mathrm{Na}$ NMR spectra of all samples. According to the NMR analysis, the chemical shifts of alkali ions are affected by both the coordination number and the kinds of nearby atoms ( $\mathrm{Si}$ or $\mathrm{B})$. The coordination characteristics of $\mathrm{Cs}^{+}$in the crystal of borosilicate glasses could help to study the immobilization mechanism of ${ }^{137} \mathrm{Cs}$ in the actual glass solidified body (Figure S3).This experimental method was effective for studying the MAE in Cs-containing glasses, and similar methods were also used in other studies [86, 87].

It can be seen that the high-temperature calcination process $\left(1100 \sim 1350^{\circ} \mathrm{C}\right)$ is an essential process for glass preparation. In the typical preparation process of borosilicate glass, $\mathrm{Cs}_{2} \mathrm{CO}_{3}$ and $\mathrm{Na}_{2} \mathrm{CO}_{3}$ could offer $\mathrm{Cs}_{2} \mathrm{O}$ and $\mathrm{Na}_{2} \mathrm{O}$ for the $\mathrm{SiO}_{2}-\mathrm{B}_{2} \mathrm{O}_{3}-\mathrm{R}_{2} \mathrm{O}$ composition system $\left(\mathrm{R}_{2} \mathrm{O}\right.$ refers to $\mathrm{Na}_{2} \mathrm{O}, \mathrm{K}_{2} \mathrm{O}$, or $\mathrm{Cs}_{2} \mathrm{O}$ ) during the high-temperature solidphase reaction. The NMR and XRD analysis results in the above studies confirmed that $\mathrm{Cs}^{+}$could enter the crystalline structure of the prepared glasses and successfully simulated the immobilization process of ${ }^{137} \mathrm{Cs}$ in the glass solidified bodies. The high temperature may inevitably cause some volatilization loss of $\mathrm{Cs}_{2} \mathrm{O}$ in the glass [77], and this can lead to numerical deviations in the quantitative analysis of $\mathrm{Cs}^{+}$. Thus, the residual $\mathrm{Cs}^{+}$content in the prepared glass samples needs to be determined in some quantitative studies, such as the leaching test of the glass solidified body.
Different from the synthesis of pollucite, $\mathrm{CsOH}$ could not be used as the raw material of glass because of its very strong alkalinity. It may react violently with the metal containers and corrode the glasses at high temperature, which will make the experiment unsafe.

2.4. Simulated ${ }^{137} \mathrm{Cs}$ in the Immobilization Method by Using Ceramic Waste Forms. Ceramic matrices exhibited more remarkable radiation resistance and chemical durability than glasses, and they were considered as the ideal hosts for immobilizing HLW [8, 44, 45].

In Yang et al.'s study [27], the (Cs, Ba)-hollandite ceramics were prepared to study the chemical evolution in the hollandite matrix due to radioactive decay $\left({ }^{137} \mathrm{Cs} \longrightarrow{ }^{137} \mathrm{Ba}\right)$, and nonradioactive ${ }^{133} \mathrm{Cs}$ and ${ }^{133} \mathrm{Ba}$ were chosen as the simulants of parent ${ }^{137} \mathrm{Cs}$ and daughter ${ }^{137} \mathrm{Ba}$, respectively. The $\left[\mathrm{Cs}_{\mathrm{x}} \mathrm{Ba}_{\mathrm{y}}\right]\left[\mathrm{Ti}_{2 y+x}^{3+} \mathrm{Ti}_{8-2 y-x}^{4+}\right] \mathrm{O}_{16} \quad(0.3<x$, $y<0.75)$ ceramics were designed for ${ }^{137} \mathrm{Cs}$ and ${ }^{137} \mathrm{Ba} \mathrm{im}-$ mobilization, and they were synthesized by a solid-state reaction method. The raw materials were $\mathrm{Cs}_{2} \mathrm{CO}_{3}, \mathrm{BaCO}_{3}$, $\mathrm{Ti}_{2} \mathrm{O}_{3}$, and $\mathrm{TiO}_{2}$, among which $\mathrm{Ti}_{2} \mathrm{O}_{3}$ was introduced to conserve the charge neutrality when $\mathrm{Cs}^{+}$ions were replaced by $\mathrm{Ba}^{2+}$ ions. The materials were preheated and weighed based on the composition of $\left[\mathrm{Cs}_{\mathrm{x}} \mathrm{Ba}_{\mathrm{y}}\right]\left[\mathrm{Ti}_{2 y+x}^{3+} \mathrm{Ti}_{8-2 y-x}^{4+}\right] \mathrm{O}_{16}$ $(0.3<x, y<0.75)$ ceramics. Then, they were homogenized in an agate mortar in ethyl alcohol by grinding and mixing for $3 \mathrm{~h}$. The mixtures were pressed into discs $(12 \mathrm{~mm}$ in diameter, $2 \mathrm{~mm}$ in thickness) at a pressure of $12 \mathrm{MPa}$ by using a hydraulic press. Then, the as-prepared discs were sintered in $5 \% \mathrm{H}_{2} / \mathrm{Ar}$ at $1250^{\circ} \mathrm{C}$ for $4 \mathrm{~h}$ to prepare the ceramic samples. Some other studies [14, 23, 88, 89] also used similar reagent-grade oxide, carbonate powders, and melt methods to prepare hollandite waste forms.

The phase composition and evolution of the ceramics were analyzed by XRD, and the microstructure evolution was detected by a Renishaw inVia Raman spectrometer, field scanning electron microscopy (FSEM), and transmission electron microscopy (TEM) coupled with energy-dispersive $\mathrm{X}$-ray spectroscopy (EDX). The EDX mapping images of the prepared $\left[\mathrm{Cs}_{0.55} \mathrm{Ba}_{0.5}\right]\left[\mathrm{Ti}_{1.55}^{3+} \mathrm{Ti}_{6.45}^{4+}\right] \mathrm{O}_{16}$ ceramic sample are shown in Figure S4 (e1, e2, e3, and e4), and all of the elements $\mathrm{Cs}, \mathrm{Ba}, \mathrm{Ti}$, and $\mathrm{O}$ were found to be homogenously distributed on the sample surface. Furthermore, the EXD spectra in Figure S4 (f1 and f2) indicated that the experimental compositions of the ceramic samples were very close to the targeted compositions, and more than $80 \%$ of Cs was retained in the ceramic sample. The results indicated that the experimental method in this study could prepare $\mathrm{Cs}, \mathrm{Ba}-$ containing ceramic samples with uniform element distribution and low nuclide loss for nuclide solidification research.

This study used the following equation to estimate the structural stability: $t_{H}=\left(\left[\left(r_{A}+r_{O}\right)^{2}-(1 / 2)\left(r_{B}+r_{O}\right)\right]^{1 / 2}\right) /$ $\left(\sqrt{3 / 2}\left(r_{B}+r_{O}\right)\right)$ [90], where $t_{H}$ is the tolerance factor, $r_{A}$ is the average ionic radii of cations in the $\mathrm{A}$ site, $r_{B}$ is the average ionic radii of cations in the $\mathrm{B}$ site, and $r_{O}$ is the oxygen ion radius $(1.4 \AA)$. The calculation results showed that the value of $t_{H}$ was close to 1 (1.033-1.097), which 
suggested that the crystalline structure of the (Cs, Ba)hollandite ceramics was stable. A diagram of the crystal structure was used to depict the evolution of simulated ${ }^{137} \mathrm{Cs}$ decay to simulated ${ }^{137} \mathrm{Ba}$ (Figure S5), which showed that the nuclides were chemically immobilized in the ceramic crystal. Overall, this study combined a Cs, Ba-containing ceramic preparation experiment, mathematical calculations, and crystal model construction, which provided comprehensive experimental methods for analyzing the immobilization and decay characteristics of simulated ${ }^{137} \mathrm{Cs}$ in the ceramic system.

In another study [20], which investigated the effects of Cs substitution on the crystal structure of phase-pure hollandite of the system, $\mathrm{Ba}_{1.15-x} \mathrm{Cs}_{2 x} \mathrm{Cr}_{2.3} \mathrm{Ti}_{5.7} \mathrm{O}_{16}(0 \leq x \leq 1.15), \mathrm{CsNO}_{3}$, $\mathrm{Ba}\left(\mathrm{O}_{2} \mathrm{C}_{2} \mathrm{H}_{3}\right)_{2}, \mathrm{Cr}\left(\mathrm{NO}_{3}\right)_{3} \cdot 9 \mathrm{H}_{2} \mathrm{O}$, and $\operatorname{Ti}\left(\mathrm{OC}_{3} \mathrm{H}_{7}\right)_{4}$ were used as starting materials for the preparation of the hollandite samples. Unlike Yang et al.'s study, the starting materials were dissolved individually in a suitable solvent and homogenized by mixing the solutions. The resultant solution was concentrated in a rotary evaporator at $90^{\circ} \mathrm{C}$ and was then calcined at $400^{\circ} \mathrm{C}$ for $4 \mathrm{~h}$ to remove all of the volatile organics. The calcined powder was pressed into discs $(20 \mathrm{~mm}$ in diameter, $3 \mathrm{~mm}$ in thickness) at a pressure of $35 \mathrm{MPa}$ for subsequent sintering at $1050^{\circ} \mathrm{C} / 4 \mathrm{~h}$. The material mixing method in this study can make the components more homogeneous, but the pretreatment process for the mixture before calcination is more complicated.

In addition to XRD analysis, time-of-flight (TOF) neutron powder diffraction (NPD) experiments were also performed for the structural analysis of phase-pure samples in this study. Furthermore, Rietveld refinement of XRD and NPD data was carried out to extract the structural features. Powder XRD data was refined by using the TOPAS 4.2 (Bruker AXS, Karlsruhe, Germany) software package in the GUI mode, starting with the tetragonal ( $\mathrm{I} 4 / \mathrm{m})$ and monoclinic $(\mathrm{I} 2 / \mathrm{m})$ structural models. Figure $\mathrm{S} 6$ shows a standard $\mathrm{I} 2 / \mathrm{m}$ hollandite unit cell with one tunnel site for $\mathrm{Ba} / \mathrm{Cs}$ (A site), two distinct crystallographic octahedral sites for $\mathrm{Cr} / \mathrm{Ti}$ (M1 and M2), and four distinct oxygen sites (O1, O2, O3, and O4). The structural models for the compositions of $\mathrm{Ba}_{1.15-x} \mathrm{Cs}_{2 x} \mathrm{Cr}_{2.3} \mathrm{Ti}_{5.7} \mathrm{O}_{16}, x=0,0.15$, and 0.25 were well developed from the Rietveld analysis of powder diffraction data (Table 3), which could help to deeply investigate the immobilization mechanism of Cs in hollandite. The results showed that approximately $35 \%$ of the Ba was replaced by Cs in the hollandite system $\mathrm{Ba}_{1.15} \mathrm{Cr}_{2.3} \mathrm{Ti}_{5.7} \mathrm{O}_{16}$.

Overall, the simulants of ${ }^{137} \mathrm{Cs}$ should be selected according to the solidified bodies and the practical experimental methods. Table 4 shows the application conditions and advantages of the simulants of ${ }^{137} \mathrm{Cs}$ in the present studies.

\section{Simulants of ${ }^{90} \mathrm{Sr}$ and Experimental Methods}

${ }^{90} \mathrm{Sr}$ is a very common beta-emitter in nuclear installations [30], which exists in wastewater, ion-selective inorganic resins, waste soils, and so on [91]. It can easily migrate into ground water due to its water solubility, and thus, it should be stabilized to prevent it from polluting the environment. $\mathrm{Sr}^{2+}$ is the main simulant of ${ }^{90} \mathrm{Sr}$ in present studies of ${ }^{90} \mathrm{Sr}$ immobilization $[32,33,62]$. In some of the studies mentioned above $[10,62,77],{ }^{90} \mathrm{Sr}$ was studied simultaneously with ${ }^{137} \mathrm{Cs}$ in the same solidified bodies in which $\mathrm{Sr}\left(\mathrm{NO}_{3}\right)_{2}$, $\mathrm{SrCO}_{3}$, and $\mathrm{SrCl}_{2} \cdot 6 \mathrm{H}_{2} \mathrm{O}$ were used as the simulants of ${ }^{90} \mathrm{Sr}$.

In the study of the immobilization of Sr by crystalline zirconium phosphate [32], $\operatorname{Sr}\left(\mathrm{NO}_{3}\right)_{2}$ was added to $\mathrm{HZr}_{2}\left(\mathrm{PO}_{4}\right)_{3}$ (molar ratios: 0.1-0.5) and mixed, and then the mixture was heated in the temperature range of $750-1200^{\circ} \mathrm{C}$ for the preparation of the $\operatorname{SrZr}_{4}\left(\mathrm{PO}_{4}\right)_{6}$ solidified body. In addition to conventional composition and structure analysis, the leaching characteristics of $\mathrm{Sr}$ in various solvents $(0.1 \mathrm{~mol} / \mathrm{L} \mathrm{HCl}$, deionized water and sea water $)$ in an autoclave at $160^{\circ} \mathrm{C}$ were also investigated. The leaching test results indicated that the crystalline proton type zirconium phosphate had excellent $\mathrm{Sr}^{2+}$ leaching resistance, which was thermally and chemically resistant in different leaching environments. In the heating process, $\mathrm{Sr}\left(\mathrm{NO}_{3}\right)_{2}$ could decompose and offer SrO for $\mathrm{SrZr}_{4}\left(\mathrm{PO}_{4}\right)_{6}$ during the hightemperature solid-phase reaction.

Walkley et al. investigated the mechanism of incorporation of Sr into metakaolin-based geopolymer gels to assess their potential as materials for the solidification of radioactive waste [92]. In this study, the activating solutions were prepared by dissolving $\mathrm{NaOH}$ and $\mathrm{KOH}$ in $\mathrm{Na}_{2} \mathrm{SiO}_{3} \cdot 9 \mathrm{H}_{2} \mathrm{O}$, and $\mathrm{Sr}(\mathrm{OH})_{2} \cdot 8 \mathrm{H}_{2} \mathrm{O}$ was added to metakaolin to produce a sample containing an isotope of $\mathrm{Sr}^{2+}$. Then, the activating solutions and metakaolin were mixed to form a homogeneous paste, which was subsequently cast in sealed containers cured for 3 months at either $20 \pm 2^{\circ} \mathrm{C}$ or $80 \pm 2^{\circ} \mathrm{C}$. The obtained molar ratio of $\mathrm{Sr} / \mathrm{Al}$ was 0.00025 , which was representative of the waste forms produced by the cementation of radioactive ion exchange resins $[31,93] . \mathrm{Sr}(\mathrm{OH})_{2}$ is easily soluble in water and can be completely ionized, and that is why it was chosen as the experimental material.

In addition to $\mathrm{Sr}\left(\mathrm{NO}_{3}\right)_{2}$ [94, 95], $\mathrm{SrCO}_{3}$ [33], and $\mathrm{Sr}(\mathrm{OH})_{2}, \mathrm{SrSO}_{4}[30]$ and $\mathrm{SrF}_{2}[34]$ were used to prepare glass or ceramic waste forms with other materials in some studies due to their high melting points $\left(>1400^{\circ} \mathrm{C}\right)$. The application conditions and advantages of the simulants of ${ }^{90} \mathrm{Sr}$ in the present studies are shown in Table 5.

\section{Simulants of Some Other Nuclides and Experimental Methods}

Except for ${ }^{137} \mathrm{Cs}$ and ${ }^{90} \mathrm{Sr}$, which have been widely studied, some other radionuclides such as ${ }^{239} \mathrm{Pu},{ }^{60} \mathrm{Co}$, and ${ }^{129} \mathrm{I}$ are also common nuclides in nuclear waste $[96,97]$. These radionuclides are usually distributed in HMW and MMW, which have strong radiation hazards $[35,98]$. It is important to pretreat and stabilize these elements prior to disposal. Therefore, many studies have been conducted to investigate the solidification/stabilization method and mechanism.

4.1. Simulants of ${ }^{239} \mathrm{Pu}$. The safe disposition of radioactive actinides $\left({ }^{239} \mathrm{Pu},{ }^{230} \mathrm{Th},{ }^{238} \mathrm{U}\right.$, etc. $)$ generated by the nuclear fuel cycle has been a major topic in the nuclear industry due to their long-term radiotoxic contribution to HLW $[26,46]$. Ceramics are considered to be suitable host 
TABLE 3: Unit cell dimensions and fit parameters from the Rietveld refinement of $\mathrm{Ba}_{1.15-x} \mathrm{Cs}_{2 x} \mathrm{Cr}_{2.3} \mathrm{Ti}_{5.7} \mathrm{O}_{16}$.

\begin{tabular}{|c|c|c|c|c|}
\hline Composition & & $x=0$ & $x=0.15$ & $x=0.25$ \\
\hline Space group & & $\mathrm{I} 4 / \mathrm{m}$ & $\mathrm{I} 2 / \mathrm{m}$ & $\mathrm{I} 2 / \mathrm{m}$ \\
\hline \multirow{6}{*}{ Unit cell parameters } & $a(\AA)$ & $10.0561(2)$ & $10.0244(6)$ & $10.192(1)$ \\
\hline & $b(\AA)$ & - & $2.9333(2)$ & $2.911(0)$ \\
\hline & $c(\AA)$ & $2.95210(7)$ & $10.0075(6)$ & $10.159(1)$ \\
\hline & $\beta$ & - & $90.058(2)$ & $90.126(3)$ \\
\hline & Volume, $V\left(\AA^{3}\right)$ & $298.53(2)$ & $298.95(3)$ & $303.34(7)$ \\
\hline & $d, \AA$ & 5.08 & 5.09 & 5.18 \\
\hline Refinement residual & $R_{\mathrm{wp}}(\%)$ & 3.72 & 3.68 & 4.83 \\
\hline
\end{tabular}

" $d$ " is the mean diagonal length of the tunnel cross section, and " $R_{\mathrm{wp}}$ " is the weighted Rietveld parameter [20].

TABLE 4: The application conditions and advantages of the simulated ${ }^{137} \mathrm{Cs}$.

\begin{tabular}{|c|c|c|c|}
\hline Simulants & Solidified body & Experimental method & Advantages \\
\hline $\begin{array}{l}\mathrm{CsNO}_{3} \text { or } \\
\mathrm{CsCl}\end{array}$ & $\begin{array}{c}\text { Cementitious } \\
\text { materials }\end{array}$ & $\begin{array}{l}\text { Dissolved in deionized water and directly } \\
\text { mixed in the solidified body for } \\
\text { immobilization }\left(<100^{\circ} \mathrm{C}\right)\end{array}$ & $\begin{array}{l}\text { Stable at low temperature, soluble in water, easy to } \\
\text { obtain }\end{array}$ \\
\hline $\mathrm{CsOH}$ & Pollucite & Hydrothermal reaction $\left(100-200^{\circ} \mathrm{C}\right)$ & $\begin{array}{l}\mathrm{OH} \text { - in } \mathrm{CsOH} \text { can be converted to } \mathrm{H}_{2} \mathrm{O} \text { by reaction; no } \\
\text { other elements were introduced into pollucite except for } \\
\text { Cs }\end{array}$ \\
\hline $\begin{array}{l}\mathrm{Cs}_{2} \mathrm{CO}_{3} \text { or } \\
\mathrm{CsNO}_{3}\end{array}$ & Glass or ceramic & Melting method $\left(1000-1350^{\circ} \mathrm{C}\right)$ & $\begin{array}{l}\text { Decompose at high temperature, releasing } \mathrm{Cs}_{2} \mathrm{O} \text { for the } \\
\text { solid-phase reaction; } \mathrm{CsOH} \text { is not used because it is } \\
\text { strongly alkaline and will react violently with the metal } \\
\text { container }\end{array}$ \\
\hline
\end{tabular}

TABLE 5: The application conditions and advantages of the simulated ${ }^{90} \mathrm{Sr}$.

\begin{tabular}{|c|c|c|c|}
\hline Simulants & Solidified body & $\begin{array}{l}\text { Experimental method and } \\
\text { temperature }\end{array}$ & Advantages \\
\hline $\begin{array}{l}\mathrm{SrCl}_{2} \cdot 6 \mathrm{H}_{2} \mathrm{O} \\
\mathrm{Sr}\left(\mathrm{NO}_{3}\right)_{2}\end{array}$ & $\begin{array}{l}\text { Cementitious } \\
\text { materials }\end{array}$ & $\begin{array}{l}\text { Directly mixed in the solidified } \\
\text { body for immobilization }\left(<100^{\circ} \mathrm{C}\right)\end{array}$ & $\begin{array}{l}\text { Soluble in water; the aqueous solution is neutral and does not } \\
\text { affect hydration }\end{array}$ \\
\hline $\mathrm{Sr}(\mathrm{OH})_{2}$ & Geopolymer gel & $\begin{array}{l}\text { Directly mixed in the solidified } \\
\text { body for immobilization }\left(<100^{\circ} \mathrm{C}\right)\end{array}$ & $\begin{array}{c}\text { Easily soluble in water, completely ionized, no other elements } \\
\text { were introduced except for Sr }\end{array}$ \\
\hline $\begin{array}{l}\mathrm{SrCO}_{3}, \mathrm{SrSO}_{4} \\
\text { or } \mathrm{SrF}_{2}\end{array}$ & Glass or ceramic & Melting method $\left(1000-1350^{\circ} \mathrm{C}\right)$ & $\begin{array}{l}\text { High melting points }\left(>1400^{\circ} \mathrm{C}\right) \text {, participates in solid-phase } \\
\text { reaction at high temperature to provide } \mathrm{SrO} \text { for the product } \\
\qquad\left(\mathrm{SrF}_{2} \text { converts to } \mathrm{SrO} \text { at }>1000^{\circ} \mathrm{C} \text { in air }\right)\end{array}$ \\
\hline $\mathrm{Sr}\left(\mathrm{NO}_{3}\right)_{2}$ & $\begin{array}{l}\text { Phosphate or } \\
\text { geopolymer }\end{array}$ & Melting method $\left(750-1200^{\circ} \mathrm{C}\right)$ & $\begin{array}{l}\text { Decomposes at high temperature (melting point is } 570^{\circ} \mathrm{C} \text { ), } \\
\text { releasing SrO for the solid-phase reaction }\end{array}$ \\
\hline
\end{tabular}

materials for the immobilization of minor actinides [99-101]. Plutonium $(\mathrm{Pu})$ is a representative actinide existing in HMW, and there has been extensive interest in using materials to immobilize it $[46,96,102]$.

Kulkarni et al. prepared $\mathrm{Pu}$-pyrochlore, $\left(\mathrm{La}_{1-x} \mathrm{Pu}_{x}\right)_{2} \mathrm{Zr}_{2} \mathrm{O}_{7}$ $(x=0 \sim 1)$, as the ceramic waste form for ${ }^{239} \mathrm{Pu}$ immobilization [25]. $\mathrm{PuO}_{2}, \mathrm{ZrO}_{2}$, graphite, and $\mathrm{La}_{2} \mathrm{O}_{3}$ were mixed in appropriate ratios and heated up to $1400^{\circ} \mathrm{C}$ in a helium atmosphere to prepare the $\mathrm{Pu}$-pyrochlore. The TG and DTA analysis results of the $2 \mathrm{PuO}_{2}+2 \mathrm{ZrO}_{2}+\mathrm{C}$ mixture are shown in Figure S7. The high-temperature chemical reaction was slow, extending over a temperature range of $1000 \sim 1400^{\circ} \mathrm{C}$ associated with a broad endothermic peak. The XRD analysis of the product indicated that it was $\mathrm{Pu}_{2} \mathrm{Zr}_{2} \mathrm{O}_{7}$, the XRD pattern of which was similar to that of $\mathrm{La}_{2} \mathrm{Zr}_{2} \mathrm{O}_{7}$. According to the XRD, TG, and DTA results, the chemical reaction could be given as follows: $2 \mathrm{PuO}_{2}+2 \mathrm{ZrO}_{2}+\mathrm{C} \longrightarrow \mathrm{Pu}_{2} \mathrm{Zr}_{2} \mathrm{O}_{7}+\mathrm{CO}$. It could be concluded that the immobilization effect of $\mathrm{Pu}$ pyrochlore on $\mathrm{Pu}$ is mainly a chemical immobilization based on the $\mathrm{Pu}$ ion entering the lattice of pyrochlore. Burakov and Anderson also used $\mathrm{PuO}_{2}$ to prepare $\mathrm{Pu}$-pyrochlore for the durability study of actinide ceramic waste forms [37]. The prepared samples showed highly physicochemical resistance to ion-saturated solutions simulating underground water after alteration experiments at $90^{\circ} \mathrm{C}$ for 3 months.

$\mathrm{PuO}_{2}$ can be used as the simulant of ${ }^{239} \mathrm{Pu}$ in the studies of nuclide solidification. However, the challenge is that $\mathrm{PuO}_{2}$ is highly toxic and has strong radioactivity, and thus, it is not proper to be used in actual experiments [103]. Many studies used $\mathrm{Ce}^{4+}$ as a substitute for $\mathrm{Pu}^{4+}$ because they have the same chemical valence state and similar ionic radii and chemical properties, and $\mathrm{CeO}_{2}$ has much lower toxicity and radioactivity than $\mathrm{PuO}_{2}[24,46,104-106]$.

In Lian et al.'s study about the ion beam irradiation in $\mathrm{La}_{2} \mathrm{Zr}_{2} \mathrm{O}_{7}-\mathrm{Ce}_{2} \mathrm{Zr}_{2} \mathrm{O}_{7}$ [46], Ce was used as an analog element for $\mathrm{Pu}$ because of the similarity with regard to the ionic size and oxidation state of $\mathrm{Ce}$ and $\mathrm{Pu}$. In the experiment, $\mathrm{CeO}_{2}$, $\mathrm{ZrO}_{2}$ and $\mathrm{La}_{2} \mathrm{O}_{3}$ powders were mixed and sintered in air at 
$1673 \mathrm{~K}$ for $32 \mathrm{~h}$ to prepare $\left(\mathrm{La}_{1-x} \mathrm{Ce}_{x}\right)_{2} \mathrm{Zr}_{2} \mathrm{O}_{7}$. Then, the prepared powders were reduced, treated, and sealed under vacuum containing residual $\mathrm{He}$ in quartz vials. The purpose of the reduction treatment was to reduce $\mathrm{Ce}(\mathrm{IV})$ to $\mathrm{Ce}(\mathrm{III})$. This is because $\mathrm{Ce}(\mathrm{IV})$ can cause a structural change from the ordered pyrochlore to a disordered defect fluorite due to the smaller ionic size $(0.097 \mathrm{~nm})$ compared to that of $\mathrm{Ce}(\mathrm{III})$ $(0.114 \mathrm{~nm})$. Ce(III) is more stable than Ce(IV) in the vacuum environment, and a single-phase stable Ce-pyrochlore is beneficial to obtaining precise experimental results. The microstructural evolution of the Ce-doped $\mathrm{La}_{2} \mathrm{Zr}_{2} \mathrm{O}_{7}$ and $\mathrm{Ce}_{2} \mathrm{Zr}_{2} \mathrm{O}_{7}$ upon ion beam irradiation was characterized by in situ transmission electron microscopy (TEM), ex situ highresolution TEM, and electron energy-loss spectrometry (EELS) techniques. According to the results, the $\mathrm{Ce}^{4+}$ fraction was estimated to be $\sim 30 \%$, suggesting that $\mathrm{Ce}^{3+}$ mainly dominated in the pyrochlore structure upon ion irradiation.

4.2. Simulants of ${ }^{60} \mathrm{Co} .{ }^{60} \mathrm{Co}$ is an isotope of cobalt (Co), which is mainly generated during the operation of nuclear reactors. It has high penetrating gamma radiation (E $\gamma$ : 1.17 MeV and $1.33 \mathrm{MeV}$ ) and a half-life of 5.26 years [36]. It mainly exists in the coolant, which is a source of serious radiation exposure to the radiation workers during normal operation [107]. Once it has entered the environment, it may be absorbed by soil or react with particles and cause health effects [108].

Some researchers studied the immobilization of ${ }^{60} \mathrm{Co}$ by using hydroxyapatite for ${ }^{60} \mathrm{Co}$-containing nuclear waste management. Ul Hassan et al. [16] studied the immobilization of Co-containing radioactive corrosion products by the cold sintering of calcium hydroxyapatite (HAp), and $\mathrm{Co}^{2+}$ was used to simulate ${ }^{60} \mathrm{Co}$. According to the previous study [108], the simulated radioactive solutions were prepared by dissolving $\mathrm{Co}\left(\mathrm{NO}_{3}\right)_{2} \cdot 6 \mathrm{H}_{2} \mathrm{O}$ salt in distilled water and adjusting the initial $\mathrm{pH}$ values of the solutions to $5.0 \pm 0.1$. In the experiment, $\mathrm{Co}^{2+}$ was absorbed by HAp, which was prepared by mixing $\left(\mathrm{NH}_{4}\right)_{2} \mathrm{HPO}_{4}$ and $\mathrm{Ca}\left(\mathrm{NO}_{3}\right)_{2} \cdot 4 \mathrm{H}_{2} \mathrm{O}$ solutions. The absorbent (Co-HAp) slurries were then dried overnight at $110^{\circ} \mathrm{C}$ in a vacuum oven. The dried Co-HAp powder was sintered by applying the optimized sintering conditions $\left(200^{\circ} \mathrm{C}, 100 \mathrm{~min}\right.$, and $\left.500 \mathrm{MPa}\right)$. The sketch of the experimental arrangement used for the cold sintering of Co-HAp is shown in Figure S8.

The measured specific surface area of the prepared HAp was $112.35 \mathrm{~m}^{2} / \mathrm{g}$, which enabled a much higher adsorption capacity of HAp than those sorbents in some typical $\mathrm{Co}^{2+}$ adsorption studies [97, 108, 109]. The results showed that $0.4 \mathrm{~g}$ of the prepared HAp could absorb $93.8 \pm 0.2 \%$ of $1 \mathrm{mM}$ $\mathrm{Co}^{2+}$ in $100 \mathrm{ml}$ of aqueous solution. After sintering at $200^{\circ} \mathrm{C}$, the Co-HAp was tested by SEM-EDS for the microstructural characterization and elemental distribution analysis. The EDS-elemental area mapping showed that the absorbed $\mathrm{Co}^{2+}$ was homogeneously distributed in the sintered matrix. The normalized leaching rate (NLRi) of the absorbed $\mathrm{Co}^{2+}$ in $\mathrm{Co}-$ HAp was then measured by a standard product consistency test (PCT). The calculated NLRi values of $\mathrm{Co}^{2+}$ were
$2.5 \times 10^{-5} \mathrm{~g} / \mathrm{m}^{2} /$ day, which is better than the release limit of $0.3 \mathrm{~g} / \mathrm{m}^{2} /$ day set by the Department of Energy (DOE) of USA for types of phosphate glass [110].

In conventional sintering methods $[111,112]$, HAp was sintered at high temperatures ranging from 900 to $1300^{\circ} \mathrm{C}$ in air. However, the high temperature can cause the decomposition or dihydroxylation of the HAp-based radioactive waste matrices [113] or the volatilization of radionuclides such as ${ }^{129} \mathrm{I}$ [114]. The cold sintering technique of HAp for the immobilization of radioactive waste is more efficient, economical, and environmentally friendly.

Venkatesan et al. used a similar simulant and experimental method [36] as above. The advantage of using $\mathrm{Co}\left(\mathrm{NO}_{3}\right)_{2} \cdot 6 \mathrm{H}_{2} \mathrm{O}$ as the source of $\mathrm{Co}^{2+}$ is that it will not affect the adsorption of $\mathrm{Co}^{2+}$ by $\mathrm{HAp}$ because $\mathrm{NO}_{3}{ }^{-}$does not further react with HAp to destroy its structure.

4.3. Simulated Radioiodine and Other Nuclear Waste. Radioactive iodine isotopes, principally ${ }^{129} \mathrm{I}$ and ${ }^{131} \mathrm{I}$, are radiation hazards emanating from the waste stream of spent fuel reprocessing facilities, which have high mobility and long half-lives (exceeding 1 million years) [115]. ${ }^{129} \mathrm{I}$ is consistently found to be one of the largest dose contributors in geologic repository performance assessments [98]. The capture and immobilization of ${ }^{129} \mathrm{I}$ are necessary in the reprocessing facility for safe disposal on a geological time scale.

Riley et al. [98] have reviewed the immobilization methods and materials of radioiodine, and a wide range of sorbents for the capture and waste forms for the immobilization of radioiodine were summarized and assessed. As described in this review, various iodine species such as $\mathrm{NaI}$, $\mathrm{NaIO}_{3}, \mathrm{HgI}_{2}$, and $\mathrm{I}_{2}(\mathrm{~g})$ were used as the simulants of ${ }^{129} \mathrm{I}$ in the current literature. Depending on the solidification approach and what form of iodine is present in the waste forms, the iodine species used as simulants of radioiodine are different.

In addition to the iodine species mentioned above, $\mathrm{NH}_{4} \mathrm{IO}_{3}$ was used as the simulant of ${ }^{129} \mathrm{I}$ in Hassan et al.'s study [35]. The cold sintering of iodine-hosted HAp for the immobilization of volatile radioiodine (I) was investigated. During the experiment, an anionic solution of $\left\{\mathrm{NH}_{4} \mathrm{IO}_{3}+\left(\mathrm{NH}_{4}\right)_{2} \mathrm{HPO}_{4}\right\}$ was mixed with a cationic solution of $\mathrm{Ca}\left(\mathrm{NO}_{3}\right)_{2} \cdot 4 \mathrm{H}_{2} \mathrm{O}$ dropwise at a flow rate of $3.3 \mathrm{ml}$, which formed a Ca:P:I molar ratio of 10:6:2. Then, IO-HAp was synthesized at $70^{\circ} \mathrm{C}$ and dried for $12 \mathrm{~h}$ at $110^{\circ} \mathrm{C}$. The cold sintering of the IO-HAp powder was carried out by applying the temperature of $200^{\circ} \mathrm{C}$, a uniaxial pressure of $500 \mathrm{MPa}$, and a holding time of $10 \mathrm{~min}$. According to the XRD, TGA/ DSC, XRF, ICP-MS characterization, and PCT test of the IOHAp powder samples, IO-HAp showed several advantages for the immobilization of ${ }^{129} \mathrm{I}$ and other volatile radionuclides for long-term geological disposal, such as simple, fast, energy-saving, and efficient solidification. The advantage of $\mathrm{NH}_{4} \mathrm{IO}_{3}$ is that $\mathrm{NH}_{4}^{+}$could be released as $\mathrm{NH}_{3}$ during the synthesis reaction of IO-HAp, which will not affect the Ca:P: I molar ratio and the crystal structure of IO-HAp. However, $\mathrm{NH}_{3}$ is harmful to the experimenters, and that is why the 
synthesis of IO-HAp was carried out in a fume hood under continuous stirring of 200 RPM [35].

Radioactive resins are problematic wastes that are produced during the ion exchange process for primary coolant purification and liquid radioactive waste treatment, which contain various radionuclides (e.g., ${ }^{137} \mathrm{Cs},{ }^{60} \mathrm{Co}$, and ${ }^{90} \mathrm{Sr}$ ) [11]. Sun et al. [116] investigated the solidification of borate radioactive resins using sulfoaluminate cement blended with zeolite. In this study, the simulated borate radioactive resins were prepared by the following steps: (i) Amberlite INR 78 resin and INR 77 resin were saturated by $\mathrm{H}_{3} \mathrm{BO}_{3}$ and $\mathrm{NaOH}$, respectively, and then mixed in a mass ratio of $1: 3$ and (ii) $\mathrm{CoCl}_{2} \cdot 6 \mathrm{H}_{2} \mathrm{O}$ and $\mathrm{CsCl}$ were added in the resins as the simulated radionuclides, and the concentrations of $\mathrm{Co}$ and $\mathrm{Cs}$ in the blended resins were $3.963 \mathrm{~g} / \mathrm{L}$ and $4.093 \mathrm{~g} / \mathrm{L}$, respectively. This preparation method for simulated radioactive resins is simple and easy to operate.

In Li et al.'s study [29], a new resin mixture of styrene base cation and anion exchange resins with a mixing ratio of 1:1 (by mass) was contacted with a known concentration of saturated solution containing $\mathrm{CsCl}$ and $\mathrm{CoCl}_{2}$ for a prolonged time (1 week). The solution contacting the resins was shaken several times every day. By this static method, the saturation of simulated resins was performed. Then, the resins were dehydrated until the moisture content decreased to $45-50 \%$ before cementation. The saturation process is a key step in the preparation of the simulated radioactive resins.

\section{Summary and Conclusions}

Simulated radionuclides are used to directly simulate the solidification and migration characteristics of the actual radionuclides in various solidified bodies. The aim of this work is to review the selection and experimental methods for the simulants of the most commonly studied radionuclides (e.g., ${ }^{137} \mathrm{Cs},{ }^{90} \mathrm{Sr},{ }^{60} \mathrm{Co},{ }^{239} \mathrm{Pu}$, and ${ }^{129} \mathrm{I}$ ) in the research of nuclear waste solidification and provide the selection basis of commonly used simulated radionuclides in various application conditions.

It is found that the nonradioactive isotopes of radionuclides are preferred as the simulants of the corresponding radionuclides because of their similar ionic radii, chemical valence state, and some other physicochemical properties. It is suggested that the simulated radionuclides are suitable for the corresponding solidified bodies and immobilization methods. In addition, the compounds containing simulated radionuclides should be nontoxic or have low toxicity and be nonradioactive or have low radioactivity to reduce the health risk to the experimenters. For ${ }^{137} \mathrm{Cs}$ solidification studies, $\mathrm{Cs}^{+}$(cesium salt) is mostly used as the simulated nuclide. $\mathrm{CsNO}_{3}, \mathrm{CsCl}, \mathrm{CsOH}, \mathrm{Cs}_{2} \mathrm{CO}_{3}$, and $\mathrm{CsNO}_{3}$ are the commonly used $\mathrm{Cs}^{+}$-containing compounds. For ${ }^{90} \mathrm{Sr}$ solidification studies, $\mathrm{Sr}^{2+}$ (strontium salt) is mostly used as the simulated nuclide. $\mathrm{SrCl}_{2} \cdot 6 \mathrm{H}_{2} \mathrm{O}, \mathrm{Sr}\left(\mathrm{NO}_{3}\right)_{2}$, $\mathrm{SrCO}_{3}, \mathrm{SrSO}_{4}$, or $\mathrm{SrF}_{2}$ is chosen to be used as the source of $\mathrm{Sr}^{2+}$. For ${ }^{239} \mathrm{Pu}$ solidification studies, $\mathrm{PuO}_{2}$ and $\mathrm{CeO}_{2}$ are mostly used as the simulants in the ceramic solidification methods occurring at high temperature. $\mathrm{Co}\left(\mathrm{NO}_{3}\right)_{2} \cdot 6 \mathrm{H}_{2} \mathrm{O}$ is commonly used as the simulant of ${ }^{60} \mathrm{Co}$, and various iodine species such as $\mathrm{NH}_{4} \mathrm{IO}_{3}, \mathrm{NaI}, \mathrm{NaIO}_{3}, \mathrm{HgI}_{2}$, and $\mathrm{I}_{2}(\mathrm{~g})$ are used as the simulants of ${ }^{129} \mathrm{I}$. For radioactive resin solidification studies, simulated radionuclides such as $\mathrm{CsCl}$ and $\mathrm{CoCl}_{2}$ are added in resins for the preparation of simulated radioactive resins. Multiple simulated nuclides can be simultaneously used in the same nuclear waste solidification experiment.

The preparation conditions of the solidified body for radionuclides, such as the temperature, phase, atmosphere, reaction principle, etc., dominate the selection of the simulants. For different solidification methods and materials, some recommendations for the selection of simulated radionuclides are summarized as follows:

(i) For cementitious material geopolymer solidification methods and cold sintering methods, the compounds containing simulated radionuclides should be soluble in water and stable at low temperature $\left(<200^{\circ} \mathrm{C}\right)$. Moreover, the $\mathrm{pH}$ value of the aqueous solution of the simulants is recommended to be close to that of the solidification environment, which will have less influence on the solidification process

(ii) For hydrothermal methods and other cold sintering methods with a reaction temperature at $\sim 200^{\circ} \mathrm{C}$, the simulated radionuclides should not introduce other elements or ions except for those mainly involved in the reactions. In this case, the reaction products containing simulated radionuclides are usually phase-pure for the sake of obtaining precise research results

(iii) For glass, ceramic, or some other solidified bodies, which are prepared by the melting methods, the simulants of radionuclides should have physicochemical stability at room temperature and can decompose at high temperature (approximately $900^{\circ} \mathrm{C} \sim 1400^{\circ} \mathrm{C}$ ) to release the oxides of simulated radionuclides for the solid-phase reactions

(iv) It is recommended that the simulated radionuclides are homogenized in the raw materials to increase the uniformity of the prepared solidified bodies, and this can improve the representativeness and validity of the test results.

This work will be beneficial in extending the applications of simulated radionuclides in new solidification materials and promoting the development of nuclear waste solidification techniques. However, there are still some other radionuclides that have not been reported in the research of nuclear waste solidification. Further studies will be conducted on the solidification methods and simulants of more radionuclides.

\section{Data Availability}

No data were used to support this study.

\section{Conflicts of Interest}

The authors declare that they have no conflicts of interest regarding the publication of this paper. 


\section{Acknowledgments}

The authors are grateful to the support of the National Engineering Laboratory of Coal-Fired Pollutants Emission Reduction, Shandong University. This work was supported by the National Key Research \& Development Program of China (No. 2017YFC0703100).

\section{Supplementary Materials}

Figure S1: the hydrothermal route for Cs-pollucite preparation. Figure S2: distribution of cations between the starting glasses and formed zeolites. Figure S3: 133Cs MAS NMR spectra of $4 \beta \mathrm{Cs} 2 \mathrm{O}-4(1-\beta) \mathrm{Na}_{2} \mathrm{O}-8 \mathrm{SiO}_{2}-2 \mathrm{~B} 2 \mathrm{O} 3$ glasses. Figure S4: element mapping and EDX spectra of [Cs0.55Ba0.5] $\left[\mathrm{Ti}_{3+1.55} \mathrm{Ti}_{4+6.45}\right] \mathrm{O}_{16}$. Figure S5: the substitution of $\mathrm{Ba}^{2+}$ for $\mathrm{Cs}^{+}$in the ceramic system. Figure S6: hollandite unit cell with I2/m symmetry. M1 and M2 are two distinct crystallography sites for octahedral cations (Cr and Ti). Figure S7: TG and DTA curves of $2 \mathrm{PuO}_{2}+2 \mathrm{ZrO}_{2}+\mathrm{C}$ in helium. Figure S8: experimental arrangement used for the cold sintering of CoHAp. (Supplementary Materials)

\section{References}

[1] J. Bouchard, Nuclear Energy, Springer, Dordrecht, Netherlands, 2012.

[2] F. J. Maringer, J. Šuráň, P. Kovář et al., "Radioactive waste management: review on clearance levels and acceptance criteria legislation, requirements and standards," Applied Radiation and Isotopes, vol. 81, pp. 255-260, 2013.

[3] M. W. A. Stewart, E. R. Vance, S. A. Moricca et al., "Immobilisation of higher activity wastes from nuclear reactor production of Mo-99," Science and Technology of Nuclear Installations, vol. 2013, Article ID 926026, 16 pages, 2013.

[4] Q. Hao, "Research on nuclear waste treatment and management strategies," M.S. thesis, North China Electric Power University, Beijing, China, 2013.

[5] X. Liu, J. Wu, L.-A. Hou, and J. Wang, "Removal of Co, Sr and Cs ions from simulated radioactive wastewater by forward osmosis," Chemosphere, vol. 232, pp. 87-95, 2019.

[6] P. Sengupta, "A review on immobilization of phosphate containing high level nuclear wastes within glass matrixpresent status and future challenges," Journal of Hazardous Materials, vol. 235-236, pp. 17-28, 2012.

[7] J. Koťátková, J. Zatloukal, P. Reiterman, and K. Kolář, "Concrete and cement composites used for radioactive waste deposition," Journal of Environmental Radioactivity, vol. 178-179, pp. 147-155, 2017.

[8] L. Wang and T. Liang, "Ceramics for high level radioactive waste solidification," Journal of Advanced Ceramics, vol. 1, no. 3, pp. 194-203, 2012.

[9] S. B. Eskander, T. A. Bayoumi, and H. M. Saleh, "Performance of aged cement-polymer composite immobilizing borate waste simulates during flooding scenarios," Journal of Nuclear Materials, vol. 420, no. 1-3, pp. 175-181, 2012.

[10] S. Fan, B. Cao, N. Deng, Y. Hu, and M. Li, "Effects of ferrihydrite nanoparticle incorporation in cementitious materials on radioactive waste immobilization," Journal of Hazardous Materials, vol. 379, Article ID 120570, 2019.
[11] J. Li and J. Wang, "Advances in cement solidification technology for waste radioactive ion exchange resins: a review," Journal of Hazardous Materials, vol. 135, no. 1-3, pp. 443-448, 2006.

[12] H. E. Saleh and S. Eskander, "Long-term effect on the solidified degraded cellulose-based waste slurry in cement matrix," Acta Montanistica Slovaca, vol. 14, pp. 291-297, 2009.

[13] A. Jan, J.-M. Delaye, S. Gin, and S. Kerisit, "Molecular dynamics simulation of ballistic effects in simplified nuclear waste glasses," Journal of Non-Crystalline Solids, vol. 505, pp. 188-201, 2019.

[14] J. Amoroso, J. C. Marra, M. Tang et al., "Melt processed multiphase ceramic waste forms for nuclear waste immobilization," Journal of Nuclear Materials, vol. 454, no. 1-3, pp. 12-21, 2014.

[15] Q. Li, Z. Sun, D. Tao et al., "Immobilization of simulated radionuclide $133 \mathrm{Cs}+$ by fly ash-based geopolymer," Journal of Hazardous Materials, vol. 262, pp. 325-331, 2013.

[16] M. Ul Hassan, S. Iqbal, J. I. Yun, and H. Jin Ryu, "Immobilization of radioactive corrosion products by cold sintering of pure hydroxyapatite," Journal of Hazardous Materials, vol. 374, 2019.

[17] J. H. Yang, H.-S. Park, and Y.-Z. Cho, "Immobilization of Cs-trapping ceramic filters within glass-ceramic waste forms," Annals of Nuclear Energy, vol. 110, pp. 1121-1126, 2017.

[18] Y. Chen, Z. Jing, K. Cai, and J. Li, "Hydrothermal conversion of Cs-polluted soil into pollucite for Cs immobilization," Chemical Engineering Journal, vol. 336, pp. 503-509, 2018.

[19] S. Kaneko, Y. Tokuda, Y. Takahashi, H. Masai, and Y. Ueda, "Structural analysis of mixed alkali borosilicate glasses containing $\mathrm{Cs}^{+}$and $\mathrm{Na}^{+}$using strong magnetic field magic angle spinning nuclear magnetic resonance," Journal of Asian Ceramic Societies, vol. 5, no. 1, pp. 7-12, 2017.

[20] P. Tumurugoti, S. K. Sundaram, and S. T. Misture, "Cesium immobilization in (Ba, Cr)-hollandites: effects on structure," Journal of Solid State Chemistry, vol. 258, pp. 72-78, 2018.

[21] X. J. Wang, H. Y. Xiao, X. T. Zu, and W. J. Weber, "A DFT ${ }_{+} \mathrm{U}$ study of cerium solubility in $\mathrm{La}_{2} \mathrm{Zr}_{2} \mathrm{O}_{7}$," Journal of Nuclear Materials, vol. 424, no. 1-3, pp. 69-74, 2012.

[22] R. E. Williford and W. J. Weber, "Computer simulation of $\mathrm{Pu}^{3+}$ and $\mathrm{Pu}^{4+}$ substitutions in gadolinium zirconate," Journal of Nuclear Materials, vol. 299, no. 2, pp. 140-147, 2001.

[23] Y. Yang, X. Wang, S. Luo, X. Yang, and J. Ma, "Stability studies of $\left[\mathrm{Cs}_{x} \mathrm{Ba}_{y}\right]\left[\left(\mathrm{Al}^{3+}, \mathrm{Ti}^{3+}\right) 2_{y+x} \mathrm{Ti}^{4+} 8-2_{y-x}\right] \mathrm{O}_{16}$ ceramics for radioactive caesium immobilization," Ceramics International, vol. 45, no. 6, pp. 7865-7870, 2019.

[24] X. Jiali, Z. Kuibao, H. Zongsheng et al., "Rapid disposal of simulated Ce-bearing radioactive soil waste using selfpropagating synthesized zirconolite-rich waste matrice," Ceramics International, vol. 44, no. 12, pp. 14534-14540, 2018.

[25] N. K. Kulkarni, S. Sampath, and V. Venugopal, "Preparation and characterisation of Pu-pyrochlore: $\left[\mathrm{La}_{1-x} \mathrm{Pu}_{x}\right]_{2} \quad \mathrm{Zr}_{2} \mathrm{O}_{7}$ $(x=0-1)$," Journal of Nuclear Materials, vol. 281, no. 2-3, pp. 248-250, 2000.

[26] C. Meng, X. Ding, J. Zhao, W. Li, C. Ren, and H. Yang, "Preparation and characterization of cerium-gadolinium monazites as ceramics for the conditioning of minor actinides," Progress in Nuclear Energy, vol. 89, pp. 1-6, 2016.

[27] Y. Yang, X. Yang, X. Wang, S. Luo, J. Ma, and Y. Huang, "Chemical evolution effects on phase and microstructure of 
$\left[\mathrm{Cs}_{x} \mathrm{Ba}_{y}\right]\left[\mathrm{Ti}^{3+} 2_{y+x} \mathrm{Ti}^{4+} 8-2 y-x\right] \mathrm{O}_{16}$ ceramic waste forms for radioactive cesium immobilization," Journal of Nuclear Materials, vol. 517, pp. 57-62, 2019.

[28] W. Gashier, T. Miura, K. Hashimoto, R. J. Hand, and H. Kinoshita, "Leaching behaviour of cementitious nuclear wasteforms containing caesium and strontium," Advances in Applied Ceramics, vol. 113, no. 8, pp. 447-452, 2014.

[29] J. Li, Z. Gang, and J. Wang, "Solidification of low-level-radioactive resins in ASC-zeolite blends," Nuclear Engineering \& Design, vol. 235, no. 7, pp. 817-820, 2005.

[30] S. Chen, X. Shu, F. Luo et al., "Rapid vitrification of simulated $\mathrm{Sr}^{2+}$ radioactive contaminated soil for nuclear emergencies," Journal of Radioanalytical and Nuclear Chemistry, vol. 319, no. 1, pp. 115-121, 2019.

[31] Y. Koma, A. Shibata, and T. Ashida, "Radioactive contamination of several materials following the fukushima daiichi nuclear power station accident," Nuclear Materials and Energy, vol. 10, pp. 35-41, 2017.

[32] S. Nakayama and K. Itoh, "Immobilization of strontium by crystalline zirconium phosphate," Journal of the European Ceramic Society, vol. 23, no. 7, pp. 1047-1052, 2003.

[33] J. A. Peterson, J. V. Crum, B. J. Riley, R. M. Asmussen, and J. J. Neeway, "Synthesis and characterization of oxyapatite $\left[\mathrm{Ca}_{2} \mathrm{Nd}_{8}\left(\mathrm{SiO}_{4}\right)_{6} \mathrm{O}_{2}\right]$ and mixed-alkaline-earth powellite [( $\mathrm{Ca}$, $\mathrm{Sr}, \mathrm{Ba}) \mathrm{MoO}_{4}$ ] for a glass-ceramic waste form," Journal of Nuclear Materials, vol. 510, 2018.

[34] M. G. Mesko, D. E. Day, and B. C. Bunker, "Immobilization of $\mathrm{CsCl}$ and $\mathrm{SrF}_{2}$ in iron phosphate glass," Waste Management, vol. 20, no. 4, pp. 271-278, 2000.

[35] M. U. Hassan and H. J. Ryu, "Cold sintering and durability of iodate-substituted calcium hydroxyapatite (IO-HAp) for the immobilization of radioiodine," Journal of Nuclear Materials, vol. 514, pp. 84-89, 2019.

[36] S. Venkatesan, M. U. Hassan, and H. J. Ryu, "Adsorption and immobilization of radioactive ionic-corrosion-products using magnetic hydroxyapatite and cold-sintering for nuclear waste management applications," Journal of Nuclear Materials, vol. 514, pp. 40-49, 2019.

[37] B. E. Burakov and E. B. Anderson, "Durability of actinide ceramic waste forms under conditions of granitoid rocks," Office of Scientific \& Technical Information Technical Reports, Tucson, AZ, USA, 2002.

[38] D. Li, I. D. Kaplan, K. A. Price et al., "Iodine immobilization by silver-impregnated granular activated carbon in cementitious systems," Journal of Environmental Radioactivity, vol. 208-209, 2019.

[39] S. Chong, J. A. Peterson, B. J. Riley et al., "Glass-bonded iodosodalite waste form for immobilization of 129I," Journal of Nuclear Materials, vol. 504, pp. 109-121, 2018.

[40] M. Chrysochoou and D. Dermatas, "Evaluation of ettringite and hydrocalumite formation for heavy metal immobilization: literature review and experimental study," Journal of Hazardous Materials, vol. 136, no. 1, pp. 20-33, 2006.

[41] R. B. Perkins and C. D. Palmer, "Solubility of chromate hydrocalumite $\left(3 \mathrm{CaO} \cdot \mathrm{Al}_{2} \mathrm{O}_{3} \cdot \mathrm{CaCrO}_{4} \cdot n \mathrm{H}_{2} \mathrm{O}\right) 5-75^{\circ} \mathrm{C}$," Cement and Concrete Research, vol. 31, no. 7, pp. 983-992, 2001.

[42] S. M. Park and J. G. Jang, "Carbonation-induced weathering effect on cesium retention of cement paste," Journal of Nuclear Materials, vol. 505, pp. 159-164, 2018.

[43] A. Guerrero, S. Goñi, M. P. Lorenzo, and J. A. Ibañez, "Development of new cement based matrices for safe disposal of hazardous metals: cadmium and caesium," Advances in Applied Ceramics, vol. 112, no. 4, pp. 190-196, 2013.
[44] W. J. Weber, A. Navrotsky, S. Stefanovsky, E. R. Vance, and E. Vernaz, "Materials science of high-level nuclear waste immobilization," MRS Bulletin, vol. 34, no. 1, pp. 46-53, 2009.

[45] Y. Zhang, E. R. Vance, and T. McLeod, "Diffuse reflectance spectroscopy of $\mathrm{Np}$ and $\mathrm{Pu}$ in zirconia and pyrochlorestructured $\mathrm{Y}_{2} \mathrm{Ti}_{2} \mathrm{O}_{7}$," Journal of Nuclear Materials, vol. 420, no. 1-3, pp. 278-281, 2012.

[46] J. Lian, M. Wangl, G. Hairer, B. Heleank, and C. Ewingr, "Ion beam irradiation in $\mathrm{La}_{2} \mathrm{Zr}_{2} \mathrm{O}_{7}-\mathrm{Ce}_{2} \mathrm{Zr}_{2} \mathrm{O}_{7}$ pyrochlore," $\mathrm{Nu}$ clear Instruments and Methods in Physics Research Section B: Beam Interactions with Materials and Atoms, vol. 218, pp. 236-243, 2004.

[47] J. Baudin, C. Adam, and J. Garnier-Laplace, "Dietary uptake, retention and tissue distribution of ${ }^{54} \mathrm{Mn},{ }^{60} \mathrm{Co}$ and ${ }^{137} \mathrm{Cs}$ in the rainbow trout (Oncorhynchus mikiss Walbaum)," Water Research, vol. 34, no. 11, pp. 2869-2878, 2000.

[48] G. Montagna, R. Arletti, G. Vezzalini, and F. Di Renzo, "Borosilicate and aluminosilicate pollucite nanocrystals for the storage of radionuclides," Powder Technology, vol. 208, no. 2, pp. 491-495, 2011.

[49] T. A. Bayoumi, "Bioaccumulation of ${ }^{137} \mathrm{Cs}$ and ${ }^{60} \mathrm{Co}$ from radioactive waste streams using Veronica anagallis-aquatica," BioTechnology: An Indian Journal, vol. 6, pp. 282-288, 2012.

[50] S. Imoto, "Chemical state of fission products in irradiated $\mathrm{UO}_{2}$," Journal of Nuclear Materials, vol. 140, no. 1, pp. 19-27, 1986.

[51] H. Kleykamp, "The chemical state of the fission products in oxide fuels," Journal of Nuclear Materials, vol. 131, no. 2-3, pp. 221-246, 1985.

[52] E. H. P. Cordfunke and R. J. M. Konings, "Chemical interactions in water-cooled nuclear fuel: a thermochemical approach," Journal of Nuclear Materials, vol. 152, no. 2-3, pp. 301-309, 1988.

[53] M. K. Jeon, J. M. Shin, J. J. Park, and G. I. Park, "Simulation of Cs behavior during the high temperature voloxidation process using the HSC chemistry code," Journal of Nuclear Materials, vol. 430, no. 1-3, pp. 37-43, 2012.

[54] J. Jokiniemi, "The growth of hygroscopic particles during severe core melt accidents," Nuclear Technology, vol. 83, no. 1, pp. 16-23, 1988.

[55] J. Yang, J. J. Ma, S. H. Ma, and X. Q. Dai, "Theoretical study of direct versus oxygen-assisted water dissociation on $\operatorname{Co}(00$ 0 1) surface," Chemical Physics Letters, vol. 681, pp. 29-35, 2017.

[56] S. Komarneni and D. M. Roy, "Mechanisms of immobilization of nuclear waste elements by cement minerals, cement and mortar," Cement and Concrete Research, vol. 11, no. 5-6, pp. 789-794, 1981.

[57] H. M. Saleh and S. B. Eskander, "Impact of water flooding on hard cement-recycled polystyrene composite immobilizing radioactive sulfate waste simulate," Construction and Building Materials, vol. 222, pp. 522-530, 2019.

[58] A. Guerrero and S. Goñi, "Efficiency of a blast furnace slag cement for immobilizing simulated borate radioactive liquid waste," Waste Management, vol. 22, no. 7, pp. 831-836, 2002.

[59] L. K. Pan, B. D. Chang, and D. S. Chou, "Optimization for solidification of low-level-radioactive resin using Taguchi analysis," Waste Management, vol. 21, no. 8, pp. 767-772, 2001.

[60] X. Shen and L. Yang, "Study on the immobilization of simulated high-level radioactive waste by alkali-activated slag cement," Chinese Journal of Nuclear Science \& Engineering, vol. 12, 1992. 
[61] T. Singh and K. Pant, "Solidification/stabilization of arsenic containing solid wastes using portland cement, fly ash and polymeric materials," Journal of Hazardous Materials, vol. 131, no. 1-3, pp. 29-36, 2006.

[62] J. G. Jang, S. M. Park, and H. K. Lee, "Physical barrier effect of geopolymeric waste form on diffusivity of cesium and strontium," Journal of Hazardous Materials, vol. 318, pp. 339-346, 2016.

[63] K. Yanagisawa, N. Yamasaki, N. Kozai, and S. Muraoka, "Leachability of waste form containing cesium produced by hydrothermal hot-pressing," Journal of Nuclear Science and Technology, vol. 27, no. 11, pp. 1072-1074, 1990.

[64] Y. Yokomori and S. Idaka, "The crystal structure of analcime," Microporous and Mesoporous Materials, vol. 21, no. 4-6, pp. 365-370, 1998.

[65] S. A. Gallagher and G. J. McCarthy, "High temperature thermal stability of $\mathrm{CsAlSiO}_{4}$ and $\mathrm{CsAlSi}_{2} \mathrm{O}_{6}$," Materials Research Bulletin, vol. 17, no. 1, pp. 89-94, 1982.

[66] H. Mimura, M. Shibata, and K. Akiba, "Hydrothermal reactions of zeolites loaded with cesium or strontium," Journal of Nuclear Science and Technology, vol. 27, no. 2, pp. 167-173, 1990.

[67] Y. Yokomori, K. Asazuki, N. Kamiya et al., "Final storage of radioactive cesium by pollucite hydrothermal synthesis," Scientific Reports, vol. 4, no. 1, p. 4195, 2015.

[68] G. D. Gatta, N. Rotiroti, T. Boffa Ballaran, C. Sanchez-Valle, and A. Pavese, "Elastic behavior and phase stability of pollucite, a potential host for nuclear waste," American Mineralogist, vol. 94, no. 8-9, pp. 1137-1143, 2009.

[69] P. Bosch, D. Caputo, B. Liguori, and C. Colella, "Safe trapping of Cs in heat-treated zeolite matrices," Journal of Nuclear Materials, vol. 324, no. 2-3, pp. 183-188, 2004.

[70] J. Fan, Z. Jing, Y. Zhang, J. Miao, Y. Chen, and F. Jin, "Mild hydrothermal synthesis of pollucite from soil for immobilization of Cs in situ and its characterization," Chemical Engineering Journal, vol. 304, pp. 344-350, 2016.

[71] J. Im, D. Seoung, S. Y. Lee et al., "Pressure-Induced metathesis reaction to sequester Cs," Environmental Science \& Technology, vol. 49, no. 1, pp. 513-519, 2015.

[72] C. M. Jantzen and N. E. Bibler, "The Product Consistency Test (ASTM C1285) for Waste Form Durability Testing," John Wiley \& Sons, Inc., Hoboken, NJ, USA, 2012.

[73] T. A. Vereshchagina, E. A. Kutikhina, C. Y. Yu et al., "Onestep immobilization of cesium and strontium from alkaline solutions via a facile hydrothermal route," Journal of Nuclear Materials, vol. 510, 2018.

[74] Z. Jing, K. Cai, Y. Li et al., "Hydrothermal synthesis of pollucite, analcime and their solid solutions and analysis of their properties," Journal of Nuclear Materials, vol. 488, pp. 63-69, 2017.

[75] S. Gin, A. Abdelouas, L. J. Criscenti et al., "An international initiative on long-term behavior of high-level nuclear waste glass," Materials Today, vol. 16, no. 6, pp. 243-248, 2013.

[76] C. M. Jantzen, D. I. Kaplan, N. E. Bibler, D. K. Peeler, and M. John Plodinec, "Performance of a buried radioactive high level waste (HLW) glass after 24 years," Journal of Nuclear Materials, vol. 378, no. 3, pp. 244-256, 2008.

[77] W. Sohn, T. Shoji, H. Kaneda, and T. Ishii, "Implications of analcime hydrothermally formed from Na-alumino-borosilicate glasses containing $\mathrm{Cs}$ and $\mathrm{Sr}$ for the stability of high-level radioactive waste form," Resource Geology, vol. 53, no. 1, pp. 51-59, 2010.
[78] D. Savage, J. E. Robbins, and R. J. Merriman, "Hydrothermal crystallization of a radioactive waste storage glass," Mineralogical Magazine, vol. 49, no. 351, pp. 195-201, 1985.

[79] A. Kidari, J.-L. Dussossoy, E. Brackx, D. Caurant, M. Magnin, and I. Bardez-Giboire, "Lanthanum and neodymium solubility in simplified $\mathrm{SiO}_{2}-\mathrm{B}_{2} \mathrm{O}_{3}-\mathrm{Na}_{2} \mathrm{O}-\mathrm{Al}_{2} \mathrm{O}_{3}$ $\mathrm{CaO}$ high level waste glass," Journal of the American Ceramic Society, vol. 95, no. 8, pp. 2537-2544, 2012.

[80] L. Li, D. M. Strachan, H. Li, L. L. Davis, and M. Qian, "Crystallization of gadolinium- and lanthanum-containing phases from sodium alumino-borosilicate glasses," Journal of Non-crystalline Solids, vol. 272, no. 1, pp. 46-56, 2000.

[81] A. Mabrouk, D. De Sousa Meneses, N. Pellerin et al., "Effects of boron on structure of lanthanum and sodium aluminoborosilicate glasses studied by X-ray diffraction, transmission electron microscopy and infrared spectrometry," Journal of Non-Crystalline Solids, vol. 503-504, pp. 69-77, 2019.

[82] D. Caurant, O. Majerus, P. Loiseau, I. Bardez, N. Baffier, and J. L. Dussossoy, "Crystallization of neodymium-rich phases in silicate glasses developed for nuclear waste immobilization," Journal of Nuclear Materials, vol. 354, no. 1-3, pp. 143-162, 2006.

[83] F. Berkemeier, S. Voss, Á. W. Imre, and H. Mehrer, "Molar volume, glass-transition temperature, and ionic conductivity of $\mathrm{Na}$ - and $\mathrm{Rb}$-borate glasses in comparison with mixed $\mathrm{Na}$ $\mathrm{Rb}$ borate glasses," Journal of Non-crystalline Solids, vol. 351, no. 52-54, pp. 3816-3825, 2005.

[84] M. Subhadra and P. Kistaiah, "Infrared and Raman spectroscopic studies of alkali bismuth borate glasses: evidence of mixed alkali effect," Vibrational Spectroscopy, vol. 62, pp. 23-27, 2012.

[85] C. P. E. Varsamis, E. I. Kamitsos, and A. Vegiri, "Molecular dynamics investigation of mixed-alkali borate glasses: shortrange order structure and alkali-ion environments," Physical Review B, vol. 80, no. 18, Article ID 184202, 2009.

[86] T. Minami, Y. Tokuda, H. Masai et al., "Structural analysis of alkali cations in mixed alkali silicate glasses by ${ }^{23} \mathrm{Na}$ and ${ }^{133} \mathrm{Cs}$ MAS NMR," Journal of Asian Ceramic Societies, vol. 2, no. 4, pp. 333-338, 2014.

[87] Y. Tokuda, Y. Takahashi, H. Masai et al., "Local structure of alkalis in mixed-alkali borate glass to elucidate the origin of mixed-alkali effect," Journal of Asian Ceramic Societies, vol. 3, no. 4, pp. 412-416, 2015.

[88] J. Amoroso, J. Marra, S. D. Conradson, M. Tang, and K. Brinkman, "Melt processed single phase hollandite waste forms for nuclear waste immobilization: $\mathrm{Ba}_{1.0} \mathrm{Cs}_{0.3} \mathrm{~A}_{2.3} \mathrm{Ti}_{5.7} \mathrm{O}_{16} ; \mathrm{A}=\mathrm{Cr}, \mathrm{Fe}, \mathrm{Al}$," Journal of Alloys and Compounds, vol. 584, pp. 590-599, 2014.

[89] H. Yang, M. Fu, B. Wu, Y. Zhang, R. Ma, and J. Qian, "Effect of $\mathrm{Fe}_{2} \mathrm{O}_{3}$ on the immobilization of high-level waste with magnesium potassium phosphate ceramic," Science and Technology of Nuclear Installations, vol. 2019, Article ID 4936379, 10 pages, 2019.

[90] S. E. Kesson and T. J. White, "Radius ratio tolerance factors and the stability of hollandites," Journal of Solid State Chemistry, vol. 63, no. 1, pp. 122-125, 1986.

[91] M. Qian, Q. Cheng, and C. Ge, "Dynamic behavior of gas bubble in single bubble sonoluminescence-vibrator model," Shengxue Xuebao/Acta Acustica, vol. 27, pp. 289-294, 2002.

[92] B. Walkley, X. Ke, O. H. Hussein, S. A. Bernal, and J. L. Provis, "Incorporation of strontium and calcium in geopolymer gels," Journal of Hazardous Materials, vol. 382, Article ID 121015, 2020. 
[93] A. Kirishima, T. Sasaki, and N. Sato, "Solution chemistry study of radioactive Sr on Fukushima daiichi NPS site," Journal of Nuclear Science and Technology, vol. 52, no. 2, pp. 152-161, 2015.

[94] D. K. Bhattacharyya and N. C. Dutta, "A study of the immobilization of strontium over crystalline titania," Journal of Materials Science, vol. 30, no. 9, pp. 2248-2250, 1995.

[95] X. Ke, S. A. Bernal, T. Sato, and J. L. Provis, "Alkali aluminosilicate geopolymers as binders to encapsulate strontiumselective titanate ion-exchangers," Dalton Transactions, vol. 48, no. 32, pp. 12116-12126, 2019.

[96] D. Bregiroux, R. Belin, P. Valenza, F. Audubert, and D. Bernache-Assollant, "Plutonium and americium monazite materials: solid state synthesis and X-ray diffraction study," Journal of Nuclear Materials, vol. 366, no. 1-2, pp. 52-57, 2007.

[97] S. Handley-Sidhu, T. K. Mullan, Q. Grail, M. Albadarneh, T. Ohnuki, and L. E. Macaskie, "Influence of $\mathrm{pH}$, competing ions and salinity on the sorption of strontium and cobalt onto biogenic hydroxyapatite," Scientific Reports, vol. 6, no. 1, Article ID 23361, 2016.

[98] B. J. Riley, J. D. Vienna, D. M. Strachan, J. S. Mccloy, and J. L. Jerden, "Materials and processes for the effective capture and immobilization of radioiodine: a review," Journal of Nuclear Materials, vol. 470, pp. 307-326, 2016.

[99] Y. Arinicheva, A. Bukaemskiy, S. Neumeier, G. Modolo, and D. Bosbach, "Studies on thermal and mechanical properties of monazite-type ceramics for the conditioning of minor actinides," Progress in Nuclear Energy, vol. 72, pp. 144-148, 2014.

[100] D. Bregiroux, O. Terra, F. Audubert et al., "Solid-state synthesis of monazite-type compounds containing tetravalent elements," Inorganic Chemistry, vol. 46, no. 24, pp. 10372-10382, 2007.

[101] O. Terra, N. Dacheux, F. Audubert, and R. Podor, "Immobilization of tetravalent actinides in phosphate ceramics," Journal of Nuclear Materials, vol. 352, no. 1-3, pp. 224-232, 2006.

[102] P. M. Kowalski, G. Beridze, V. L. Vinograd, and D. Bosbach, "Heat capacities of lanthanide and actinide monazite-type ceramics," Journal of Nuclear Materials, vol. 464, pp. 147154, 2015.

[103] H. Y. Xiao, M. Jiang, F. A. Zhao, Z. J. Liu, and X. T. Zu, "Thermal and mechanical stability, electronic structure and energetic properties of $\mathrm{Pu}$-containing pyrochlores: $\mathrm{La}_{2}-\mathrm{Pu}$ $\mathrm{Zr}_{2} \mathrm{O}_{7}$ and $\mathrm{La}_{2} \mathrm{Zr}_{2}-\mathrm{Pu} \mathrm{O}_{7}(0 \leq y \leq 2)$," Journal of Nuclear Materials, vol. 466, pp. 162-171, 2015.

[104] H. S. Kim, C. Y. Joung, B. H. Lee, J. Y. Oh, Y. H. Koo, and P. Heimgartner, "Applicability of $\mathrm{CeO}_{2}$ as a surrogate for $\mathrm{PuO}_{2}$ in a MOX fuel development," Journal of Nuclear Materials, vol. 378, no. 1, pp. 98-104, 2008.

[105] S. S. Shoup, C. E. Bamberger, J. L. Tyree, and L. M. Anovitz, "Lanthanide-containing zirconotitanate solid solutions," Journal of Solid State Chemistry, vol. 127, no. 2, pp. 231-239, 1996.

[106] S. J. Patwe and A. K. Tyagi, "Solubility of $\mathrm{Ce}^{4+}$ and $\mathrm{Sr}^{2+}$ in the pyrochlore lattice of $\mathrm{Gd}_{2} \mathrm{Zr}_{2} \mathrm{O}_{7}$ for simulation of $\mathrm{Pu}$ and alkaline earth metal," Ceramics International, vol. 32, no. 5, pp. 545-548, 2006.

[107] C. C. Lin, "A review of corrosion product transport and radiation field buildup in boiling water reactors," Progress in Nuclear Energy, vol. 51, no. 2, pp. 207-224, 2009.
[108] I. Smičiklas, S. Dimović, I. Plećaš, and M. Mitrić, "Removal of $\mathrm{Co}^{2+}$ from aqueous solutions by hydroxyapatite," Water Research, vol. 40, no. 12, pp. 2267-2274, 2006.

[109] N. Gupta, A. K. Kushwaha, and M. C. Chattopadhyaya, "Adsorptive removal of $\mathrm{Pb}^{2+}, \mathrm{Co}^{2+}$ and $\mathrm{Ni}^{2+}$ by hydroxyapatite/chitosan composite from aqueous solution," Journal of the Taiwan Institute of Chemical Engineers, vol. 43, pp. 125-131, 2012.

[110] I. W. Donald, B. L. Metcalfe, and R. N. J. Taylor, "The immobilization of high level radioactive wastes using ceramics and glasses," Journal of Materials Science, vol. 32, no. 22, pp. 5851-5887, 1997.

[111] E. Champion, "Sintering of calcium phosphate bioceramics," Acta Biomaterialia, vol. 9, no. 4, pp. 5855-5875, 2013.

[112] G. Muralithran and S. Ramesh, "The effects of sintering temperature on the properties of hydroxyapatite," Ceramics International, vol. 26, no. 2, pp. 221-230, 2000.

[113] A. Karimzadeh, M. R. Ayatollahi, A. R. Bushroa, and M. K. Herliansyah, "Effect of sintering temperature on mechanical and tribological properties of hydroxyapatite measured by nanoindentation and nanoscratch experiments," Ceramics International, vol. 40, no. 7, pp. 9159-9164, 2014.

[114] A. Coulon, D. Laurencin, A. Grandjean et al., "Key parameters for spark plasma sintering of wet-precipitated iodatesubstituted hydroxyapatite," Journal of the European Ceramic Society, vol. 36, no. 8, pp. 2009-2016, 2016.

[115] D. Laurencin, D. Vantelon, V. Briois et al., "Investigation of the local environment of iodate in hydroxyapatite by combination of X-ray absorption spectroscopy and DFT modeling," RSC Advances, vol. 4, no. 28, pp. 14700-14707, 2014.

[116] Q. Sun, J. Li, and J. Wang, "Solidification of borate radioactive resins using sulfoaluminate cement blending with zeolite," Nuclear Engineering and Design, vol. 241, no. 12, pp. 5308-5315, 2011. 